\title{
WAIS Divide ice core suggests sustained changes in the atmospheric formation pathways of sulfate and nitrate since the 19th century in the extratropical Southern Hemisphere
}

\author{
E. D. Sofen ${ }^{1}$, B. Alexander ${ }^{1}$, E. J. Steig ${ }^{2}$, M. H. Thiemens ${ }^{3}$, S. A. Kunasek ${ }^{2}$, H. M. Amos ${ }^{1, *}$, A. J. Schauer ${ }^{2}$, \\ M. G. Hastings ${ }^{1, * *}$, J. Bautista ${ }^{2}$, T. L. Jackson ${ }^{3}$, L. E. Vogel $^{4}$, J. R. McConnell ${ }^{5}$, D. R. Pasteris ${ }^{5}$, and E. S. Saltzman ${ }^{6}$ \\ ${ }^{1}$ Department of Atmospheric Sciences, University of Washington, Seattle, WA 98195, USA \\ ${ }^{2}$ Department of Earth and Space Sciences, University of Washington, Seattle, WA 98195, USA \\ ${ }^{3}$ University of California at San Diego, La Jolla, CA 92093, USA \\ ${ }^{4}$ Joint Institute for the Study of the Atmosphere and the Ocean, University of Washington, Seattle, WA 98195, USA \\ ${ }^{5}$ Division of Hydrologic Sciences, Desert Research Institute, Reno, NV 89512, USA \\ ${ }^{6}$ Department of Earth System Science, University of California at Irvine, Irvine, CA 92697, USA \\ * now at: Department of Earth and Planetary Sciences, Harvard University, Cambridge, MA 02138, USA \\ ** now at: Department of Geological Sciences, Brown University, Providence, RI 02912, USA
}

Correspondence to: E. D. Sofen (esofen@atmos.uw.edu)

Received: 24 July 2013 - Published in Atmos. Chem. Phys. Discuss.: 3 September 2013

Revised: 24 April 2014 - Accepted: 28 April 2014 - Published: 11 June 2014

\begin{abstract}
The ${ }^{17} \mathrm{O}$ excess $\left(\Delta^{17} \mathrm{O}=\delta^{17} \mathrm{O}-0.52 \times \delta^{18} \mathrm{O}\right)$ of sulfate and nitrate reflects the relative importance of their different production pathways in the atmosphere. A new record of sulfate and nitrate $\Delta^{17} \mathrm{O}$ spanning the last 2400 years from the West Antarctic Ice Sheet Divide ice core project shows significant changes in both sulfate and nitrate $\Delta^{17} \mathrm{O}$ in the most recent 200 years, indicating changes in their formation pathways. The sulfate $\Delta^{17} \mathrm{O}$ record exhibits a $1.1 \%$ increase in the early 19 th century from $(2.4 \pm 0.2) \%$ o to $(3.5 \pm 0.2) \%$, which suggests that an additional $12-18 \%$ of sulfate formation occurs via aqueous-phase production by $\mathrm{O}_{3}$, relative to that in the gas phase. Nitrate $\Delta^{17} \mathrm{O}$ gradually decreases over the whole record, with a more rapid decrease between the mid-19th century and the present day of $5.6 \%$, indicating an increasing importance of $\mathrm{RO}_{2}$ in $\mathrm{NO}_{\mathrm{x}}$ cycling between the mid-19th century and the present day in the mid- to highlatitude Southern Hemisphere. The former has implications for the climate impacts of sulfate aerosol, while the latter has implications for the tropospheric $\mathrm{O}_{3}$ production rate in remote low- $\mathrm{NO}_{\mathrm{x}}$ environments. Using other ice core observations, we rule out drivers for these changes other than variability in extratropical oxidant $\left(\mathrm{OH}, \mathrm{O}_{3}, \mathrm{RO}_{2}, \mathrm{H}_{2} \mathrm{O}_{2}\right.$, and reactive halogens) concentrations. However, assuming $\mathrm{OH}$,
\end{abstract}

$\mathrm{H}_{2} \mathrm{O}_{2}$, and $\mathrm{O}_{3}$ are the main oxidants contributing to sulfate formation, Monte Carlo box model simulations require a large $(\geq 260 \%)$ increase in the $\mathrm{O}_{3} / \mathrm{OH}$ mole fraction ratio over the Southern Ocean in the early 19th century to match the sulfate $\Delta^{17} \mathrm{O}$ record. This unlikely scenario points to a deficiency in our understanding of sulfur chemistry and suggests other oxidants may play an important role in sulfate formation in the mid- to high-latitude marine boundary layer. The observed decrease in nitrate $\Delta^{17} \mathrm{O}$ since the mid19 th century is most likely due to an increased importance of $\mathrm{RO}_{2}$ over $\mathrm{O}_{3}$ in $\mathrm{NO}_{\mathrm{x}}$ cycling and can be explained by a $60-90 \%$ decrease in the $\mathrm{O}_{3} / \mathrm{RO}_{2}$ mole fraction ratio in the extratropical Southern Hemisphere $\mathrm{NO}_{\mathrm{X}}$-source regions.

\section{Introduction}

The formation pathways of tropospheric sulfate $\left(\mathrm{SO}_{4}{ }^{2-}\right)$ and nitrate $\left(\mathrm{NO}_{3}{ }^{-}\right)$impact atmospheric chemistry and climate in a number of ways. The importance of gas-phase versus aqueous-phase sulfate formation will impact the contribution of sulfate aerosols to direct scattering of solar radiation and indirect radiative effects via changes in cloud 
microphysics. Gas-phase $\mathrm{SO}_{4}{ }^{2-}$ production has the potential to increase sulfate aerosol and $\mathrm{CCN}$ concentrations (Langner et al., 1992), while aqueous-phase production in existing droplets can enhance the ability of those particles to act as $\mathrm{CCN}$ at lower supersaturations (Kaufman and Tanre, 1994). Changes in nitrogen oxides $\left(\mathrm{NO}_{\mathrm{x}}=\mathrm{NO}+\mathrm{NO}_{2}\right)$ cycling and nitrate aerosol formation impact $\mathrm{O}_{3}$ production rates and the lifetime of $\mathrm{NO}_{\mathrm{x}}$, with implications for the oxidizing capacity of the atmosphere. Oxygen isotope measurements from ice cores can provide insight into the formation pathways of sulfate and nitrate aerosol and how they change over time (Alexander et al., 2002, 2003, 2004; Hastings et al., 2005). Quantitatively connecting changes in the oxygen isotopes of sulfate and nitrate to changes in atmospheric conditions remains a key challenge in the application of these measurements to paleo-chemistry.

A key control on the formation pathways of sulfate and nitrate is the abundance of the oxidants involved in their formation. Atmospheric oxidants such as ozone $\left(\mathrm{O}_{3}\right)$ and the hydroxyl radical $(\mathrm{OH})$ play a central role in determining the chemical makeup of the troposphere, as their concentrations determine the lifetime and fate of reduced trace gases and the formation of aerosols including sulfate and nitrate, with implications for climate and air pollution. Atmospheric oxidant concentrations are strongly influenced by emissions of $\mathrm{O}_{3}$ precursors such as carbon monoxide $(\mathrm{CO})$, methane $\left(\mathrm{CH}_{4}\right)$, volatile organic carbon (VOC) species, and nitrogen oxides, and are fundamentally coupled to each other via oxidant cycling. Reactive halogens (e.g., BrO) also impact the chemistry of oxidants, sulfate, and nitrate in a number of ways (von Glasow et al., 2004; Morin et al., 2007; Saiz-Lopez and von Glasow, 2012).

Our knowledge of past variability in the abundance of atmospheric oxidants is very limited. Global chemical transport models (CTM) have been used to investigate oxidant changes based on emissions changes between the preindustrial (prior to 1750,1800 , or $1850 \mathrm{CE}$ ) and the present day (between 1990 and 2010 CE). Most models suggest an increase in global tropospheric $\mathrm{O}_{3}(+25 \%$ to $+63 \%)$, an even larger increase in $\mathrm{H}_{2} \mathrm{O}_{2}(+44 \%$ to $+130 \%)$, but no consistent agreement in the sign or magnitude of the change in $\mathrm{OH}$ $(-33 \%$ to $+14 \%)$, although most suggest $\mathrm{OH}$ has decreased slightly (Sofen et al., 2011; John et al., 2012, and references therein). These global averages largely reflect changes in the tropics and Northern mid-latitudes where oxidant concentrations are the highest. The lifetime of $\mathrm{CH}_{4}$, which is controlled by $\mathrm{OH}$, is also largely determined in the tropics (Holmes et al., 2013). However, the abundance and isotopic composition of shorter-lived species such as sulfate and nitrate preserved in Antarctic ice cores is determined by processes in mid-to-high southern latitudes. Ice core measurements of hydrogen peroxide $\left(\mathrm{H}_{2} \mathrm{O}_{2}\right)$ indicate a $50 \%$ increase in its Antarctic boundary layer concentration during the 20th century due to a combination of the large-scale influence of increases in $\mathrm{CO}$ and $\mathrm{CH}_{4}$ emissions and the local increase in tropospheric $\mathrm{O}_{3}$ photolysis (producing $\mathrm{HO}_{2}$, a precursor of $\mathrm{H}_{2} \mathrm{O}_{2}$ ) over Antarctica due to the stratospheric ozone hole since the 1970s (Lamarque et al., 2011). Late 19th century measurements of surface $\mathrm{O}_{3}$ using the Schönbein method suggest very low preindustrial surface ozone mole fraction $\mathrm{x}\left(\mathrm{O}_{3}\right)$ around $10 \mathrm{nmol} \mathrm{mol}^{-1}$ (Sandroni et al., 1992; Pavelin et al., 1999) at a number of sites in both hemispheres, implying that human activity in the 20th century has increased surface $\mathrm{x}\left(\mathrm{O}_{3}\right)$ by approximately $100 \%$ in remote regions, although there is considerable uncertainty surrounding the reconstruction of these historic measurements. Because oxidants are generally not well preserved in any paleo-archive, there is no other direct evidence of the magnitude of past oxidant changes. The triple oxygen isotopes of sulfate and nitrate from ice cores have been suggested as a potential constraint on local to regional paleo-oxidant changes because the sulfate and nitrate preserve the isotopic composition of the oxidants involved in their formation. However, their interpretation is complicated by other factors influencing sulfate and nitrate chemistry and uncertainty in the spatial scale reflected by measurements at a single location.

The first measurements of the triple-oxygen isotopes of sulfate from the West Antarctic Ice Sheet (WAIS) Divide ice coring project (http://www.waisdivide.unh.edu/) spanning 1774-2005 CE show an increase in the early 19th century, with stable values from the mid-19th century to the present (Kunasek et al., 2010). The lack of changes since the mid-19th century is consistent with increases in both $\mathrm{O}_{3}$ and $\mathrm{H}_{2} \mathrm{O}_{2}$, because they have offsetting effects on the sulfate isotopes (Kunasek et al., 2010; Sofen et al., 2011). The present work extends this record back another 2000 years and includes the complementary measurement of nitrate isotopes. We compare these isotope records to other ice core chemical records and consider possible explanations for the observed variability in the $\Delta^{17} \mathrm{O}$ record.

\section{Background}

The ${ }^{17} \mathrm{O}$ excess $\left(\Delta^{17} \mathrm{O}=\delta^{17} \mathrm{O}-0.52 \times \delta^{18} \mathrm{O}\right)$ is an approximate measure of the deviation from mass-dependent fractionation of $\delta^{17} \mathrm{O}$ and $\delta^{18} \mathrm{O}$. The formation of ozone produces a large positive $\Delta^{17} \mathrm{O}$ (Thiemens and Heidenreich, 1983) that is then passed to other atmospheric species through oxidation reactions (Thiemens, 2006).

The mean and standard deviation of all $\Delta^{17} \mathrm{O}\left(\mathrm{O}_{3}\right)$ observations is $25 \pm 5 \%$ (Krankowsky et al., 1995; Johnston and Thiemens, 1997; Vicars et al., 2012), although due to the low abundance of ozone and potential interfering gases, all of these methods may be subject to low biases (Brenninkmeijer et al., 2003). Because of the possible low bias in the observations, studies of sulfate or nitrate $\Delta^{17} \mathrm{O}$ have assumed $\Delta^{17} \mathrm{O}\left(\mathrm{O}_{3}\right)$ ranging between $25 \%$ and $35 \%$ (Michalski et al., 2003; Morin et al., 2007; Kunasek et al., 2010; Morin et al., 2011; Sofen et al., 2011; Alexander et al., 
2012). A global modeling study suggests that $\Delta^{17} \mathrm{O}\left(\mathrm{O}_{3}\right)=$ $35 \%$ agrees best with global observations of $\Delta^{17} \mathrm{O}\left(\mathrm{NO}_{3}{ }^{-}\right)$ (Alexander et al., 2009). In this study, we use $\Delta^{17} \mathrm{O}\left(\mathrm{O}_{3}\right)$ $=25 \%$ o to be consistent with observations, but do sensitivity studies assuming $35 \%$. The isotopic anomaly in ozone is preferentially distributed to the terminal oxygen atoms such that $\Delta^{17} \mathrm{O}\left(\mathrm{O}_{3}\right)_{\text {term }}=1.5 \Delta{ }^{17} \mathrm{O}\left(\mathrm{O}_{3}\right)_{\text {bulk }}$ (Savarino et al., 2008). Depending on the reaction involving ozone, the resulting isotopic composition may reflect either that of the $\Delta^{17} \mathrm{O}\left(\mathrm{O}_{3}\right)_{\text {term }}$ or $\Delta^{17} \mathrm{O}\left(\mathrm{O}_{3}\right)_{\text {bulk }}$.

Observations show $\quad \Delta^{17} \mathrm{O}\left(\mathrm{H}_{2} \mathrm{O}_{2}\right)=(1.3 \pm 0.3) \%$ o (Savarino and Thiemens, 1999). Generally, $\Delta^{17} \mathrm{O}(\mathrm{OH})=$ $0 \%$ o due to rapid isotopic exchange with water vapor (Dubey et al., 1997; Lyons, 2001), but in polar regions where water vapor concentrations are low, $\mathrm{OH}$ may retain a small fraction of the positive $\Delta^{17} \mathrm{O}$ acquired from $\mathrm{O}_{3}$ (Morin et al., 2007). Observations show $\Delta^{17} \mathrm{O}\left(\mathrm{O}_{2}\right)=-0.34 \%$ (Barkan and Luz, 2005).

Sulfate and nitrate both acquire a mass-independent (nonzero $\Delta{ }^{17} \mathrm{O}$ ) oxygen isotopic composition from the oxidants involved in their formation. The main oxidants relevant to nitrate formation are $\mathrm{O}_{3}, \mathrm{RO}_{2}$ ( $\mathrm{R}=\mathrm{H}$ atom or organic group), $\mathrm{OH}$, and $\mathrm{BrO}$, while sulfate formation involves primarily $\mathrm{O}_{3}$, $\mathrm{H}_{2} \mathrm{O}_{2}$, and $\mathrm{OH}$. Hypohalous acids ( $\mathrm{HOCl}$ and $\mathrm{HOBr}$ ) may also be important oxidants for sulfate formation in the marine boundary layer (Vogt et al., 1996; von Glasow et al., 2002), but the rate constant for the reactions $\mathrm{HOBr} / \mathrm{HOCl}+\mathrm{HSO}_{3}{ }^{-}$ are unknown (Liu, 2002). Sulfate and nitrate $\Delta^{17} \mathrm{O}$ is influenced solely by the relative importance of their formation pathways (Savarino et al., 2000; Michalski et al., 2003), which depends upon the relative abundance of the different oxidants, the isotopic composition of each oxidant, and the number of oxygen atoms transferred during oxidation.

In addition to the uncertainty in the present-day value of $\Delta^{17} \mathrm{O}\left(\mathrm{O}_{3}\right)$, it is possible that $\Delta^{17} \mathrm{O}\left(\mathrm{O}_{3}\right)$ has varied with time due to variations in the relative importance of the flux of stratospheric $\mathrm{O}_{3}$ to the troposphere compared with in situ tropospheric ozone production. In situ production has become increasingly important for the tropospheric ozone burden in the industrial era due to anthropogenic emissions of ozone precursors (Lelieveld and Dentener, 2000). Measured stratospheric and tropospheric $\Delta^{17} \mathrm{O}\left(\mathrm{O}_{3}\right)$ show considerable overlap, with the tropospheric $\Delta^{17} \mathrm{O}\left(\mathrm{O}_{3}\right)$ observations ranging from 17 to $37 \%$ and stratospheric $\Delta{ }^{17} \mathrm{O}\left(\mathrm{O}_{3}\right)$ ranging from 25 to $41 \%$ o (mean and standard deviation of $33 \pm 4 \%$ ) (Krankowsky et al., 2007, and references therein). The higher $\Delta{ }^{17} \mathrm{O}\left(\mathrm{O}_{3}\right)$ value for $\mathrm{O}_{3}$ formed in the stratosphere is due to pressure and temperature effects during $\mathrm{O}_{3}$ formation (Feilberg et al., 2013; Guenther et al. , 1999). As an upper bound, we estimate the change in $\Delta^{17} \mathrm{O}\left(\mathrm{O}_{3}\right)$ by assuming a shift from $60 \%$ stratospheric to $40 \%$ stratospheric contribution to high southern latitude $\mathrm{O}_{3}$ during the transition from the preindustrial to industrial period following Lelieveld and Dentener (2000) and assuming a stratospheric $\Delta^{17} \mathrm{O}\left(\mathrm{O}_{3}\right)=33 \%$ and tropospheric $\Delta^{17} \mathrm{O}\left(\mathrm{O}_{3}\right)=$
$25 \%$. Such a change in $\Delta^{17} \mathrm{O}\left(\mathrm{O}_{3}\right)$ would lower $\Delta{ }^{17} \mathrm{O}\left(\mathrm{O}_{3}\right)$ by up to $2.6 \%$ from the preindustrial to the industrial period. Using more recent calculations from the Atmospheric Chemistry and Climate Model Intercomparison Project (ACCMIP) (Young et al., 2013) suggests a change in $\Delta^{17} \mathrm{O}\left(\mathrm{O}_{3}\right)$ of $0.4 \%$ o to $1.8 \%$. These calculations are highly uncertain due to uncertainties in the preindustrial ozone budget and stratosphere-troposphere exchange; however, the influence on $\Delta^{17} \mathrm{O}\left(\mathrm{O}_{3}\right)$ is are small compared to the uncertainty in $\Delta^{17} \mathrm{O}\left(\mathrm{O}_{3}\right)$ and the magnitude of the observed changes in nitrate $\Delta^{17} \mathrm{O}$. Lacking further information, we assume that $\Delta{ }^{17} \mathrm{O}\left(\mathrm{O}_{3}\right)$ is constant over the time period studied here.

\subsection{Sulfate chemistry and $\Delta^{17} \mathrm{O}$}

While anthropogenic emissions dominate the present-day Northern Hemisphere sulfur budget, marine biogenic emissions of dimethyl sulfide (DMS) and sea-salt sulfate represent the majority of Southern Hemisphere sulfur emissions (Bates et al., 1992; Seinfeld and Pandis, 2006). Poleward of $35^{\circ} \mathrm{S},>75 \%$ of sulfur emissions are from marine sources (Spiro et al., 1992). Most DMS is oxidized by $\mathrm{OH}, \mathrm{NO}_{3}$, and $\mathrm{BrO}$ to $\mathrm{SO}_{2}$ and then to $\mathrm{SO}_{4}{ }^{2-}$, and most of the remainder forms methanesulfonic acid (MSA). The yield of MSA relative to $\mathrm{SO}_{2}$ from DMS oxidation is enhanced at lower temperatures (Arsene et al., 1999) or when the oxidant is $\mathrm{BrO}$ rather than $\mathrm{OH}$ (Read et al., 2008).

The main tropospheric sulfate formation pathways are summarized in Fig. 1a. The rate of sulfate production by each oxidation pathway is determined by oxidant concentrations and several other factors. $\mathrm{SO}_{2}$ is oxidized by $\mathrm{OH}$ in the gas phase, forming sulfuric acid $\left(\mathrm{H}_{2} \mathrm{SO}_{4}\right) \cdot \mathrm{SO}_{2}$ may also dissolve into cloud droplets, speciating into $\mathrm{S}(\mathrm{IV})$ (= $\mathrm{SO}_{2} \cdot \mathrm{H}_{2} \mathrm{O}+\mathrm{HSO}_{3}{ }^{-}+\mathrm{SO}_{3}{ }^{2-}$ ), where it may react with $\mathrm{H}_{2} \mathrm{O}_{2}$, $\mathrm{O}_{3}$, hypohalous acids or $\mathrm{O}_{2}$ catalyzed by transition metals $\mathrm{Fe}(\mathrm{III})$ and $\mathrm{Mn}(\mathrm{II})$ to form sulfate. Cloud cover and liquid water content impact the relative importance of gas versus aqueous-phase sulfate production. Cloud water $\mathrm{pH}$ influences $\mathrm{S}(\mathrm{IV})$ speciation and therefore the sulfate production rate by $\mathrm{O}_{3}$. Finally, heterogeneous sulfate formation by $\mathrm{O}_{3}$ may occur on the surface of sea salt and dust aerosols, and thus depends upon the available aerosol surface area. The lifetime of sulfate to loss via wet and dry deposition is about one week (Park et al., 2004). The $\Delta^{17} \mathrm{O}\left(\mathrm{SO}_{4}{ }^{2-}\right)$ value of sulfate formed by $\mathrm{OH}$ oxidation is approximately $0 \%$, that by $\mathrm{H}_{2} \mathrm{O}_{2}$ is approximately $0.65 \%$ o, and $\mathrm{O}_{2}$ is $-0.09 \%$ o. Here, we assume the bulk $\Delta{ }^{17} \mathrm{O}\left(\mathrm{O}_{3}\right)=25 \%$, resulting in a sulfate isotopic composition of $6.25 \%$, but also conduct sensitivity studies using $\Delta^{17} \mathrm{O}\left(\mathrm{O}_{3}\right)=35 \%$, forming sulfate with $\Delta^{17} \mathrm{O}\left(\mathrm{SO}_{4}{ }^{2-}\right)=8.75 \%$. Sulfate formed by $\mathrm{HOCl}$ or $\mathrm{HOBr}$ has $\Delta^{17} \mathrm{O}\left(\mathrm{SO}_{4}{ }^{2-}\right)$ near $0 \%$, as the reaction proceeds via hydrolysis, so the oxygen atom comes from a water molecule (Fogelman et al., 1989; Troy and Margerum, 1991). 


\subsection{Nitrate chemistry and $\Delta^{17} \mathrm{O}$}

Nitrogen oxides are emitted into or produced in the atmosphere via high-temperature processes including fossil fuel combustion, biomass burning, and lightning as well as via soil microbes and the atmospheric oxidation of ammonia. Reaction of $\mathrm{N}_{2} \mathrm{O}$ with $\mathrm{O}\left({ }^{1} \mathrm{D}\right)$ in the stratosphere produces $\mathrm{NO}_{\mathrm{x}}$ that enters the polar troposphere either via gas-phase stratosphere-troposphere mixing or, after conversion to nitrate, via sedimentation of stratospheric aerosols (Salawitch et al., 1989). Finally, photolysis of snowpack nitrate releases $\mathrm{NO}_{\mathrm{x}}$ to the polar boundary layer that may re-deposit locally or elsewhere in Antarctica (Blunier et al., 2005; Frey et al., 2009; Erbland et al., 2013). Isotopic evidence suggests that nitrate at an East Antarctic coastal site is derived from snowpack $\mathrm{NO}_{\mathrm{x}}$ emissions upslope on the East Antarctic plateau (Savarino et al., 2007). Antarctic boundary layer meteorology suggests that WAIS Divide is located in an area of lowlevel divergence of the katabatic winds and likely sees little transport across the Transantarctic Mountains from East Antarctica (Parish and Bromwich, 2007), suggesting that WAIS Divide is not strongly influenced by fluxes of $\mathrm{NO}_{\mathrm{x}}$ and $\mathrm{NO}_{3}{ }^{-}$from East Antarctica in the present day. Recent trace gas observations combined with NOAA Hysplit backtrajectory analysis starting from $10 \mathrm{~m}$ above the surface at WAIS Divide find that during a three-week study period, $27 \%$ of air masses came from the East Antarctic Plateau, with an additional $41 \%$ contribution from lower elevations $(<2500 \mathrm{~m})$ East Antarctic locations (Masclin et al., 2013). However, they find that the lifetime of $\mathrm{NO}_{\mathrm{x}}$ and $\mathrm{HNO}_{3}$ is short enough that East Antarctica is not expected to be a major source of $\mathrm{NO}_{\mathrm{x}}$ or nitrate to WAIS Divide in the present day. The relative importance of these $\mathrm{NO}_{\mathrm{x}}$ sources to nitrate deposited in West Antarctica and how they may have varied on long timescales is not well quantified (Wolff et al., 2008) and remains a topic of active research.

In sunlight (daytime or polar summer), $\mathrm{NO}_{\mathrm{x}}$ cycles rapidly via oxidation of $\mathrm{NO}$ by $\mathrm{O}_{3}, \mathrm{RO}_{2}$, or $\mathrm{BrO}$ and photolysis of $\mathrm{NO}_{2}$. Figure $1 \mathrm{~b}$ illustrates the major nitrate formation pathways. $\mathrm{NO}_{2}$ is oxidized in the daytime by $\mathrm{OH}$ to form $\mathrm{HNO}_{3}$ or by $\mathrm{BrO}$ to $\mathrm{BrONO}_{2}$. Formation of $\mathrm{BrONO}_{2}$ is followed by hydrolysis to form $\mathrm{HNO}_{3}$ on the surface of aerosols. At night, $\mathrm{NO}_{2}$ is oxidized by $\mathrm{O}_{3}$ to form the nitrate radical $\left(\mathrm{NO}_{3}\right)$, followed by conversion to $\mathrm{HNO}_{3}$ via hydrogen abstraction of either DMS or hydrocarbons ( $\mathrm{HC}$ ) or by $\mathrm{N}_{2} \mathrm{O}_{5}$ hydrolysis on the surface of aerosols. During daytime, $\mathrm{NO}_{3}$ is photolyzed back to $\mathrm{NO}_{\mathrm{x}}$, preventing significant daytime nitric acid production by these latter reactions. Once formed, aerosol thermodynamics determine the partitioning of nitric acid between the gas phase and aerosol phase. In the aerosol phase, $\mathrm{HNO}_{3}$ may dissolve in water and dissociate into $\mathrm{H}^{+}+\mathrm{NO}_{3}{ }^{-}$. The oxygen isotopic compositions of $\mathrm{HNO}_{3}$ and $\mathrm{NO}_{3}{ }^{-}$are indistinguishable, as gas-aerosol partitioning will only produce a mass-dependent fractionation. References to "nitrate" and $\Delta^{17} \mathrm{O}\left(\mathrm{NO}_{3}{ }^{-}\right)$refer to the sum of $\mathrm{HNO}_{3}+\mathrm{NO}_{3}{ }^{-}$and its
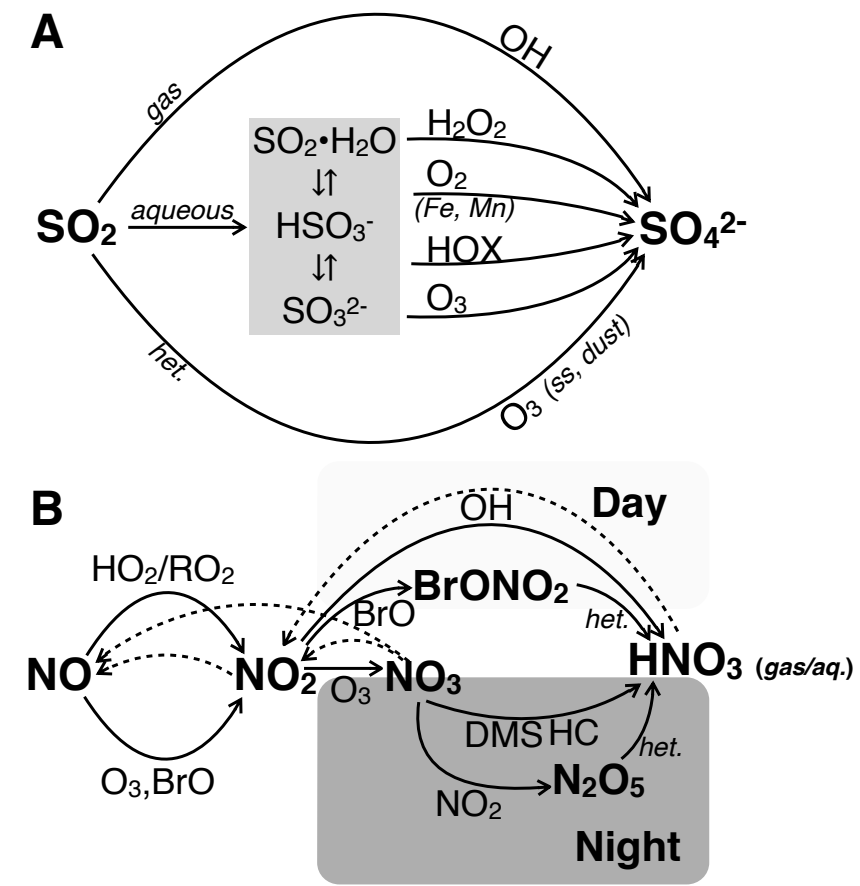

Figure 1. Summary of major (A) sulfate production pathways and (B) nitrate production pathways. "HOX" $=\mathrm{HOBr}$ or $\mathrm{HOCl}$; "ss" = sea salt; "het." = heterogeneous reactions on the surface of aerosols. $\mathrm{HNO}_{3}$ formed through the heterogeneous reactions is formed in the aqueous phase, while the other pathways produce gas-phase $\mathrm{HNO}_{3} \cdot \mathrm{HNO}_{3}$ partitions between gas and aqueous phases based on aerosol thermodynamics. Aqueous-phase $\mathrm{HNO}_{3}$ may dissociate into $\mathrm{H}^{+}+\mathrm{NO}_{3}{ }^{-}$. Dashed lines indicate photolysis reactions.

isotopic composition, unless otherwise specified. The global average lifetime of nitrate is 4-6 days and is lost from the atmosphere via dry and wet deposition to the surface $(\mathrm{Xu}$ and Penner, 2012).

The oxygen isotopic composition of nitrate $\left(\Delta^{17} \mathrm{O}\left(\mathrm{NO}_{3}{ }^{-}\right)\right)$is determined by the isotopic composition of $\mathrm{NO}_{2}\left(\Delta^{17} \mathrm{O}\left(\mathrm{NO}_{2}\right)\right)$ and the oxidation pathways of $\mathrm{NO}_{2}$ to nitrate. The $\Delta^{17} \mathrm{O}\left(\mathrm{NO}_{2}\right)$ is determined by the relative abundance of $\mathrm{O}_{3}, \mathrm{RO}_{2}$, and $\mathrm{BrO} . \mathrm{NO}_{2}$ formed by $\mathrm{O}_{3}$ exhibits a higher isotopic value than the bulk $\Delta^{17} \mathrm{O}\left(\mathrm{O}_{3}\right)$, as the isotopic anomaly in $\mathrm{O}_{3}$ is preferentially positioned in the terminal oxygen atoms that are transferred to $\mathrm{NO}_{2}$ (Savarino et al., 2008). Since, two of the three oxygen atoms in nitrate come from $\mathrm{NO}_{2}, \Delta^{17} \mathrm{O}\left(\mathrm{NO}_{3}{ }^{-}\right)$equals $\frac{2}{3} \Delta^{17} \mathrm{O}\left(\mathrm{NO}_{2}\right)$, plus the isotopic anomaly transferred in the oxidation of $\mathrm{NO}_{2}$ to nitrate. For a given value of $\Delta^{17} \mathrm{O}\left(\mathrm{NO}_{2}\right), \mathrm{NO}_{2}+\mathrm{OH}$ produces the lowest $\Delta^{17} \mathrm{O}\left(\mathrm{NO}_{3}{ }^{-}\right)$value, and $\mathrm{NO}_{3}+\mathrm{DMS} / \mathrm{HC}$ or $\mathrm{BrONO}_{2}$ hydrolysis produce the highest $\Delta^{17} \mathrm{O}\left(\mathrm{NO}_{3}{ }^{-}\right)$. Observations of $\Delta^{17} \mathrm{O}\left(\mathrm{NO}_{3}{ }^{-}\right)$from Antarctic aerosol range from 20 to $43.1 \%$ (Savarino et al., 2007). Postdepositional processing also impacts $\Delta^{17} \mathrm{O}\left(\mathrm{NO}_{3}{ }^{-}\right)$. When snowpack $\mathrm{NO}_{3}{ }^{-}$is photolyzed, released to the boundary layer as $\mathrm{NO}_{\mathrm{x}}$, and oxidized back to $\mathrm{NO}_{3}{ }^{-}$, it acquires a $\Delta^{17} \mathrm{O}$ reflecting 
oxidant abundances local to the sunlit Antarctic boundary layer.

\subsection{Nitrate $\delta^{15} \mathrm{~N}$}

The nitrogen isotopic composition of nitrate $\left(\delta^{15} \mathrm{~N}\left(\mathrm{NO}_{3}{ }^{-}\right)\right)$ in snow and ice is thought to be mainly influenced by the source of $\mathrm{NO}_{\mathrm{x}}$ and the extent of postdepositional loss of nitrate from the snowpack (Morin et al., 2009; Savarino et al., 2007). $\mathrm{NO}_{\mathrm{x}}$ sources span a range of $\delta^{15} \mathrm{~N}\left(\mathrm{NO}_{\mathrm{x}}\right)=-49$ to $+25 \%$ (Felix et al., 2012, and references therein), but are uncertain due in part to fractionation during $\mathrm{NO}_{\mathrm{x}}$ collection (Fibiger and Hastings, 2012). Mid-latitude aerosol measurements of $\delta^{15} \mathrm{~N}\left(\mathrm{NO}_{3}{ }^{-}\right)$suggest a narrower range, with anthropogenically influenced $\delta^{15} \mathrm{~N}\left(\mathrm{NO}_{3}{ }^{-}\right)=0-6 \%$, while nitrate from natural $\mathrm{NO}_{\mathrm{x}}$ sources has $\delta^{15} \mathrm{~N}\left(\mathrm{NO}_{3}{ }^{-}\right)=(-4 \pm 2) \%$ o (Morin et al., 2009).

Photolysis of nitrate in snowpack followed by ventilation of the released $\mathrm{NO}_{\mathrm{x}}$ enriches snowpack $\delta^{15} \mathrm{~N}\left(\mathrm{NO}_{3}{ }^{-}\right.$) and is a source of low- $\delta^{15} \mathrm{~N} \mathrm{NO}_{\mathrm{x}}$ to the boundary layer (Honrath et al. , 1999; Blunier et al., 2005). However, the magnitude of the fractionation factor due to photolysis remains uncertain (Erbland et al., 2013), and the actual impact on snowpack $\delta^{15} \mathrm{~N}\left(\mathrm{NO}_{3}{ }^{-}\right)$depends on the extent to which $\mathrm{NO}_{\mathrm{x}}$ is exported from a site before redeposition. The amount of postdepositional loss, and therefore the extent of snowpack $\delta^{15} \mathrm{~N}\left(\mathrm{NO}_{3}{ }^{-}\right)$enrichment, depends upon snow accumulation rate (Frey et al., 2009) and the concentration of UV absorbing impurities in the snow (Zatko et al., 2013). The extent to which snowpack $\mathrm{NO}_{\mathrm{x}}$ is emitted from the snow to the overlying atmosphere and the extent to which that $\mathrm{NO}_{\mathrm{x}}$ is transported before oxidation and redeposition remains highly uncertain due to challenges in both the measurement and modeling of snowpack and polar boundary layer $\mathrm{NO}_{\mathrm{x}}$. Low-accumulation rate $\left(0.027-0.035 \mathrm{~m} \mathrm{a}^{-1}\right.$ water equivalent at Dome C) East Antarctic Plateau sites have snowpack $\delta^{15} \mathrm{~N}\left(\mathrm{NO}_{3}{ }^{-}\right)$up to $340 \%$ (Erbland et al., 2013).

\section{Methods}

\subsection{Description of the WAIS Divide site and cores}

The West Antarctic Ice Sheet Divide (WAIS Divide) ice core site is located at $79.467^{\circ} \mathrm{S}, 112.085^{\circ} \mathrm{W}$ at a surface elevation of $1176 \mathrm{~m}$. The site was selected due to its proximity $24 \mathrm{~km}$ downslope from the ice flow divide - providing good ice stratigraphy - and its present-day annual accumulation rate of $(0.22 \pm 0.04) \mathrm{m} \mathrm{a}^{-1}$ water equivalent - comparable to Greenland summit ice cores. The accumulation rate is calculated based on annual layer thickness corrected for ice flow strain and densification and is found to have declined gradually over the past 2400 years from a maximum of $0.28 \mathrm{~m} \mathrm{a}^{-1}$, with very little change since $1700 \mathrm{CE}(\mathrm{Fe}-$ gyveresi et al., 2011). An accumulation rate comparable to that in Greenland allows for direct comparison of many ice core records between hemispheres. The high accumulation rate at the site also has the potential to mitigate the impact of postdepositional processes on many chemical species such as $\mathrm{H}_{2} \mathrm{O}_{2}$ and nitrate. In addition to a long core (WDC06A) that almost reaches the ice sheet bed, a number of short cores of approximately $100 \mathrm{~m}$ were drilled to provide greater ice volume for studies of the recent past and development of new analytical techniques.

\subsection{Ice core sampling}

The upper $577 \mathrm{~m}$ of the WAIS Divide ice core, spanning the time period from $427 \mathrm{BCE}$ to $2006 \mathrm{CE}$ with a dating uncertainty of approximately $\pm 2 \%$ (McGwire et al., 2011), was sampled for measurement of the isotopic composition of sulfate and nitrate. Ice samples from the WAIS Divide ice cores were cut at the National Ice Core Lab (NICL; Denver, CO, USA). Each section consisted of a $3 \mathrm{~cm} \times 3 \mathrm{~cm}$ cross section pieces, generally $1 \mathrm{~m}$ in length. Based upon concentration measurements, $1 \mathrm{~m}$ sections were combined to achieve sample sizes adequate for isotopic analysis. Low sulfate concentrations in the ice required the combination of 7-15 $\mathrm{m}$ of ice per isotopic analysis, corresponding to $27-68$ a of snow accumulation per sample.

Table 1 summarizes the sampling and isotopic measurement scheme. Sulfate isotope measurements were conducted on six samples from the WDC05A core between the surface and $69.80 \mathrm{~m}$ and were previously published (Kunasek et al., 2010). Nitrate $\delta^{15} \mathrm{~N}$ was measured on 70 samples of approximately $1 \mathrm{~m}$ length from the surface to $69.80 \mathrm{~m}$ in the WDC05A core. Nitrate $\Delta^{17} \mathrm{O}$ was measured at $1 \mathrm{~m}$ resolution on 121 samples between the surface and $129.196 \mathrm{~m}$ in the WDC05Q core. The $1 \mathrm{~m}$ resolution $\delta^{15} \mathrm{~N}\left(\mathrm{NO}_{3}{ }^{-}\right)$and $\Delta^{17} \mathrm{O}\left(\mathrm{NO}_{3}{ }^{-}\right)$were measured on separate ice cores because the process of evaporating the melted ice sample on a low $\left(60^{\circ} \mathrm{C}\right)$ hot plate in a laminar flow clean hood to concentrate the nitrate for $\Delta^{17} \mathrm{O}\left(\mathrm{NO}_{3}{ }^{-}\right)$analysis was found to fractionate $\delta^{15} \mathrm{~N}\left(\mathrm{NO}_{3}{ }^{-}\right)$. Upon adoption of a new method of concentrating nitrate using an anion exchange resin following Frey et al. (2009), all three sets of isotopes, $\Delta^{17} \mathrm{O}\left(\mathrm{SO}_{4}{ }^{2-}\right)$, $\Delta^{17} \mathrm{O}\left(\mathrm{NO}_{3}{ }^{-}\right)$, and $\delta^{15} \mathrm{~N}\left(\mathrm{NO}_{3}{ }^{-}\right)$, were measured on thirtytwo samples from the WDC06A core between $114 \mathrm{~m}$ and $577 \mathrm{~m}$

\subsection{Isotopic analysis}

\subsubsection{Nitrate isotopes}

For the 32 samples measured on the WDC06A core, after melting the ice samples in a laminar flow clean hood, $500 \mathrm{~mL}$ aliquots were taken for nitrate isotope analysis. All nitrate isotope measurements on the WDC06A core were conducted in triplicate. The melt water samples are concentrated using the anion exchange resin prior to conversion of nitrate to $\mathrm{N}_{2} \mathrm{O}$ via bacterial denitrification using 
Table 1. Ice core sampling resolution and isotopic measurements.

\begin{tabular}{|c|c|c|c|c|}
\hline Core & $\begin{array}{l}\text { Depth range }(\mathrm{m}) \\
\text { Time range }\end{array}$ & $\begin{array}{l}\text { Depth res. (m) } \\
\text { Time res. (a) }\end{array}$ & $\begin{array}{r}\text { No. of samples } \\
\text { (No. of replicates) }\end{array}$ & Measurements \\
\hline WDC05A & $\begin{array}{c}0-69.8 \\
1774-2005 \mathrm{CE}\end{array}$ & $\begin{array}{c}7.03-12.86 \\
27-44\end{array}$ & $\begin{array}{r}6 \\
(1)\end{array}$ & $\Delta^{17} \mathrm{O}\left(\mathrm{SO}_{4}{ }^{2-}\right)$ \\
\hline WDC05A & $\begin{array}{c}0-69.8 \\
1774-2005 \mathrm{CE}\end{array}$ & $\begin{array}{c}0.875-1.12 \\
1.8-4.8\end{array}$ & $\begin{array}{r}70 \\
(1)\end{array}$ & $\delta^{15} \mathrm{~N}\left(\mathrm{NO}_{3}{ }^{-}\right)$ \\
\hline WDC05Q & $\begin{array}{c}0-129.17 \\
1521-2000 \mathrm{CE}\end{array}$ & $\begin{array}{c}0.546-1.37 \\
2.3-6.1\end{array}$ & $\begin{array}{r}121 \\
(3)\end{array}$ & $\Delta^{17} \mathrm{O}\left(\mathrm{NO}_{3}{ }^{-}\right)$ \\
\hline WDC06A & $\begin{array}{c}114-577 \\
427 \mathrm{BCE}-1586 \mathrm{CE}\end{array}$ & $\begin{array}{l}12-15 \\
50-68\end{array}$ & $\begin{array}{r}32 \\
(1)\end{array}$ & $\Delta^{17} \mathrm{O}\left(\mathrm{SO}_{4}{ }^{2-}\right)$ \\
\hline WDC06A & $\begin{array}{c}114-577 \\
427 \mathrm{BCE}-1586 \mathrm{CE}\end{array}$ & $\begin{array}{l}12-15 \\
50-68\end{array}$ & $\begin{array}{l}32 \\
(3)\end{array}$ & $\Delta^{17} \mathrm{O}\left(\mathrm{NO}_{3}{ }^{-}\right)$ \\
\hline WDC06A & $\begin{array}{c}114-577 \\
427 \text { BCE-1586 CE }\end{array}$ & $\begin{array}{l}12-15 \\
50-68\end{array}$ & $\begin{array}{l}32 \\
(3)\end{array}$ & $\delta^{15} \mathrm{~N}\left(\mathrm{NO}_{3}{ }^{-}\right)$ \\
\hline
\end{tabular}

Table 2. Sulfate model isotope assumptions.

\begin{tabular}{lr}
\hline Pathway & Sulfate $\Delta^{17} \mathrm{O}(\%$ o $)$ \\
\hline $\mathrm{SO}_{2}+\mathrm{OH}$ & 0.0 \\
$\mathrm{~S}(\mathrm{IV})+\mathrm{H}_{2} \mathrm{O}_{2}$ & 0.6 \\
$\mathrm{~S}(\mathrm{IV})+\mathrm{O}_{3}$ & $\frac{1}{4} \Delta^{17} \mathrm{O}\left(\mathrm{O}_{3}\right)_{\text {bulk }}$ \\
$\mathrm{S}(\mathrm{IV})+\mathrm{O}_{2}$ & -0.1 \\
$\mathrm{~S}(\mathrm{IV})+\mathrm{HOCl} / \mathrm{HOBr}$ & 0.0 \\
\hline
\end{tabular}

Pseudomonas aureofaciens. The $\mathrm{N}_{2} \mathrm{O}$ is then decomposed into $\mathrm{O}_{2}+\mathrm{N}_{2}$ in a heated gold tube in a quantitative manner for isotopic analysis of $\delta^{15} \mathrm{~N}$ and $\Delta^{17} \mathrm{O}$ (Sigman et al., 2001; Kaiser et al., 2007).

The samples at $1 \mathrm{~m}$ resolution were measured prior to those from the WDC06A core and underwent a slightly different process.

The upper $69.80 \mathrm{~m}$ of the WDC05A core was sampled at $1 \mathrm{~m}$ resolution for $\delta^{15} \mathrm{~N}\left(\mathrm{NO}_{3}{ }^{-}\right)$analysis. Seventy ice samples were melted in a laminar flow clean hood, and aliquots were taken (without pre-concentration) for conversion of nitrate to $\mathrm{N}_{2} \mathrm{O}$ via bacterial denitrification using Pseudomonas chlororaphis, which allows for smaller samples than $P$. $a u$ reofaciens, and measured via continuous flow isotope ratio mass spectrometry. Duplicates were conducted at 10 depths.

For the $114 \Delta^{17} \mathrm{O}\left(\mathrm{NO}_{3}{ }^{-}\right)$measurements on the WDC05Q core, ice samples were melted and then pre-concentrated by evaporation on a hot plate in the laminar flow clean hood. The sample nitrate was then converted to $\mathrm{N}_{2} \mathrm{O}$ and $\Delta^{17} \mathrm{O}\left(\mathrm{NO}_{3}{ }^{-}\right)$ was measured as described above for the WDC06A samples, although only $\Delta^{17} \mathrm{O}\left(\mathrm{NO}_{3}{ }^{-}\right)$measurements were used, not $\delta^{15} \mathrm{~N}$.

Nitrate $\Delta^{17} \mathrm{O}\left(\mathrm{NO}_{3}{ }^{-}\right)$and $\delta^{15} \mathrm{~N}\left(\mathrm{NO}_{3}{ }^{-}\right)$are measured relative to VSMOW and air $\mathrm{N}_{2}$, respectively. Their values are corrected for nonlinearity associated with sample size based on replicate measurements of international
(USGS-34: $\Delta^{17} \mathrm{O}\left(\mathrm{NO}_{3}{ }^{-}\right)=-0.1 \%$ and $\delta^{15} \mathrm{~N}\left(\mathrm{NO}_{3}{ }^{-}\right)=$ $1.8 \%$; USGS-35: $\Delta^{17} \mathrm{O}\left(\mathrm{NO}_{3}{ }^{-}\right)=21.6 \%$; and IAEA-N3: $\delta^{15} \mathrm{~N}\left(\mathrm{NO}_{3}{ }^{-}\right)=4.7 \%$ ) and in-house laboratory standards over a range of sizes. Uncertainty in the $\delta^{15} \mathrm{~N}\left(\mathrm{NO}_{3}{ }^{-}\right)$from the WDC06A core and all $\Delta^{17} \mathrm{O}\left(\mathrm{NO}_{3}{ }^{-}\right)$measurements is the maximum of the standard deviation of the triplicate measurement due to inter-sample variability or uncertainty in the yield correction. A fixed uncertainty of $\pm 0.55 \%$ is used for $\delta^{15} \mathrm{~N}\left(\mathrm{NO}_{3}{ }^{-}\right)$from the WDC05A core, based on the $1 \sigma$ error in the 10 duplicate measurements.

\subsubsection{Sulfate isotopes}

The rest of the melt water (approximately 6-14 L), intended for sulfate isotope analysis, was heated on a hot plate to $60^{\circ} \mathrm{C}$ in a laminar flow hood to concentrate the sample by evaporation to approximately $50 \mathrm{~mL}$ volume. Sulfate was separated from other anions using a Dionex 2000 ion chromatograph with an IonPac AG15 column $(4 \times 50 \mathrm{~mm})$ for anion preconcentration, IonPac AG19 guard column $(4 \times 50 \mathrm{~mm})$, IonPac AS19 separation column $(4 \times 250 \mathrm{~mm})$, ASRS-Ultra II suppressor $(4 \mathrm{~mm})$, and Dionex conductivity detector. The extracted sulfate (as $\mathrm{H}_{2} \mathrm{SO}_{4}$ solution) was frozen and shipped to UCSD where it was converted to $\mathrm{Ag}_{2} \mathrm{SO}_{4}$ using an $\mathrm{Ag}^{+}$ exchange resin. The $\Delta^{17} \mathrm{O}\left(\mathrm{SO}_{4}{ }^{2-}\right)$ was measured at UCSD using the silver salt pyrolysis method described by Kunasek et al. (2010) and Savarino et al. (2001), except that sulfur isotopes were not measured beyond the upper $70 \mathrm{~m}$ as they proved difficult to interpret (Kunasek et al., 2010). Due to sample size requirements, only a single $\Delta^{17} \mathrm{O}\left(\mathrm{SO}_{4}{ }^{2-}\right)$ analysis was performed for each depth interval.

Sulfate $\Delta^{17} \mathrm{O}$ is first corrected for isotopic exchange with quartz (Schauer et al., 2012) then for sea-salt sulfate based on high-resolution $\mathrm{Na}^{+}$measurements from continuous-flow analysis (performed at the Desert Research Institute (DRI)) averaged to the resolution of the isotope measurements. We assume a sulfate-to-sodium ratio of $k=0.25$ (Holland, 
Table 3. Nitrate model isotope assumptions.

\begin{tabular}{ll}
\hline Pathway & Product $\Delta^{17} \mathrm{O}(\%)$ \\
\hline $\mathrm{NO}+\mathrm{HO}_{2} \rightarrow \mathrm{NO}_{2}$ & 0.0 \\
$\mathrm{NO}+\mathrm{O}_{3} \rightarrow \mathrm{NO}_{2}$ & $1.18 \times \Delta^{17} \mathrm{O}\left(\mathrm{O}_{3}\right)_{\text {bulk }}+6.6$ \\
$\mathrm{NO}+\mathrm{BrO} \rightarrow \mathrm{NO}_{2}$ & $1.5 \times \Delta^{17} \mathrm{O}_{\text {bulk }}$ \\
\hline $\mathrm{NO}_{2}+\mathrm{O}_{3} \stackrel{\mathrm{DMS}, \mathrm{HC}}{\longrightarrow} \mathrm{HNO}_{3}$ & $\frac{1}{3}\left(1.23 \times \Delta^{17} \mathrm{O}\left(\mathrm{O}_{3}\right)_{\text {bulk }}+9.0\right)+\frac{2}{3} \Delta \Delta^{17} \mathrm{O}\left(\mathrm{NO}_{2}\right)$ \\
$\mathrm{NO}_{2}+\mathrm{O}_{3} \stackrel{\mathrm{N}_{5}}{\longrightarrow} \mathrm{HNO}_{3}$ & $\frac{1}{2}\left[\frac{1}{3}\left(1.23 \times \Delta^{17} \mathrm{O}\left(\mathrm{O}_{3}\right)_{\text {bulk }}+9.0\right)+\frac{2}{3} \Delta^{17} \mathrm{O}\left(\mathrm{NO}_{2}\right)\right]+\frac{1}{3} \Delta^{17} \mathrm{O}\left(\mathrm{NO}_{2}\right)$ \\
$\mathrm{NO}_{2}+\mathrm{BrO} \rightarrow \mathrm{HNO}_{3}$ & $\frac{1}{3}\left(1.5 \times \Delta^{17} \mathrm{O}\left(\mathrm{O}_{3}\right)_{\text {bulk }}\right)+\frac{2}{3} \Delta^{17} \mathrm{O}\left(\mathrm{NO}_{2}\right)$ \\
$\mathrm{NO}_{2}+\mathrm{OH} \rightarrow \mathrm{HNO}_{3}$ & $\frac{2}{3} \Delta^{17} \mathrm{O}\left(\mathrm{NO}_{2}\right)$ \\
\hline
\end{tabular}

1978). An uncertainty in the $\Delta^{17} \mathrm{O}\left(\mathrm{SO}_{4}{ }^{2-}\right)$ measurements of $\pm 0.3 \%$ is determined from the $1 \sigma$ error in the repeated measurement of standards.

\subsection{Box model description}

To interpret the observations of $\Delta^{17} \mathrm{O}\left(\mathrm{SO}_{4}{ }^{2-}\right)$ and $\Delta^{17} \mathrm{O}\left(\mathrm{NO}_{3}{ }^{-}\right)$to changes in mid- to high-latitude Southern Hemisphere oxidant abundances, we developed a Monte Carlo modeling framework for box models of the production and isotopic composition of sulfate and nitrate.

\subsubsection{Model design}

The nitrate box model chemistry was previously described by Kunasek et al. (2008). The sulfate box model chemistry scheme is the same as that used in sulfate isotope simulations in the GEOS-Chem (http://www.geos-chem.org) global three-dimensional chemical transport model (Bey et al., 2001; Park et al., 2004; Alexander et al., 2012). Both box models calculate monthly mean production rates for each pathway described in Sects. 2.1 and 2.2 and shown in Fig. 1. The sulfate model goes a step further to calculate concentrations based on the production rates from the box model using Southern Ocean boundary conditions and the global mean lifetime for each form of sulfate (gas-phase, aqueous, or heterogeneous) based on a global sulfate aerosol simulation (Alexander et al., 2009). This step is not necessary for nitrate, because the thermodynamic partitioning of nitrate between gas and aerosol phases means that the lifetime of nitrate is independent of its production mechanism.

Convolving the models monthly mean production rates (nitrate) and concentrations (sulfate) associated with each formation mechanism, the oxidant isotopic composition, and isotopic transfer associated with each pathway shown in Tables 2 and 3 allows the calculation of the monthly and annual mean isotopic compositions of sulfate and nitrate. The sulfate $\Delta^{17} \mathrm{O}$ calculation utilises the concentration of sulfate formed by each oxidation pathway and its corresponding isotopic composition as shown in Table 2. The $\Delta^{17} \mathrm{O}\left(\mathrm{SO}_{4}{ }^{2-}\right)$ values shown in Table 2 are based on the experimental results of Savarino et al. (2000). The nitrate calculation is somewhat complicated by the two-step oxidation of $\mathrm{NO}$ to $\mathrm{NO}_{3}{ }^{-}$. The nitrate model first calculates the ratio of the steady-state production rates of $\mathrm{NO}_{2}$ by $\mathrm{O}_{3}$ and $\mathrm{RO}_{2}$ and the isotopic composition of $\mathrm{NO}_{2}$ is calculated based on this ratio and the isotopic composition of $\mathrm{O}_{3}$ and $\mathrm{RO}_{2}$. This represents $2 / 3$ of the final isotopic composition of the nitrate. This is followed by the oxidation of $\mathrm{NO}_{2}$ to $\mathrm{NO}_{3}{ }^{-}$by $\mathrm{OH}$ or to $\mathrm{NO}_{3}$ by $\mathrm{O}_{3}$ followed by $\mathrm{N}_{2} \mathrm{O}_{5}$ formation and hydrolysis or hydrogen abstraction by DMS or hydrocarbons to form $\mathrm{NO}_{3}{ }^{-}$. In oxidation of $\mathrm{NO}_{2}$ by $\mathrm{OH}$, since we assume $\Delta^{17} \mathrm{O}(\mathrm{OH})$ is $0, \Delta^{17} \mathrm{O}\left(\mathrm{NO}_{3}{ }^{-}\right)$is simply $\frac{2}{3} \Delta^{17} \mathrm{O}\left(\mathrm{NO}_{2}\right)$. The isotopic transfer functions associated with the other oxidation pathways are shown in Table 3. To account for the internal isotopic distribution of ozone, we use the isotopic transfer function of Savarino et al. (2008) for $\mathrm{NO}+\mathrm{O}_{3}$ and that of Berhanu et al. (2012) for $\mathrm{NO}_{2}+\mathrm{O}_{3}$ and assume that for reactions involving $\mathrm{BrO}$, the oxygen comes entirely from the terminal oxygen atom of ozone Morin et al. (2007); Vicars et al. (2012).

Halogen chemistry is included in both nitrate and sulfate models as a sensitivity study. In the nitrate model, we include both $\mathrm{NO}+\mathrm{BrO}$ and $\mathrm{NO}_{2}+\mathrm{BrO}$ followed by the hydrolysis of $\mathrm{BrONO}_{2}$ on aerosols as in Kunasek et al. (2008). In the sulfate model, we include aqueous-phase sulfate production by both $\mathrm{HOBr}$ and $\mathrm{HOCl}$ using assumed (for $\mathrm{HSO}_{3}{ }^{-}$) and measured (for $\mathrm{SO}_{3}{ }^{2-}$ ) reaction rate constants (Fogelman et al., 1989; Troy and Margerum, 1991).

\subsubsection{Model boundary conditions}

Box model boundary conditions are generally taken from a GEOS-Chem simulation of the year 2005 for the geographical region of interest (Southern Ocean and South American boundary layers for sulfate and nitrate, respectively). For the nitrate model, the fraction of the month in daylight is calculated based on latitude $\left(50^{\circ} \mathrm{S}\right)$.

Sulfate model boundary conditions include concentrations of $\mathrm{SO}_{2}, \mathrm{HNO}_{3}, \mathrm{O}_{3}, \mathrm{OH}, \mathrm{H}_{2} \mathrm{O}_{2}$, dust (in four size bins: 0.1$1.0,1.0-1.8,1.8-3.0,3.0-6.0 \mu \mathrm{m}$ ), and sea salt (in two size bins: $0.1-0.5,0.5-10 \mu \mathrm{m})$. Physical parameters include air density, temperature, specific humidity, and surface pressure. 
For aqueous phase chemistry, cloud water $\mathrm{pH}$ is varied between 4.5 and 6.0 to span the $\mathrm{pH}$ range across which aqueous sulfate formation and $\Delta^{17} \mathrm{O}\left(\mathrm{SO}_{4}{ }^{2-}\right)$ are highly sensitive to $\mathrm{pH}$. Observations of cloud water $\mathrm{pH}$ in clean marine environments span a range of 3.8-6.1 (Faloona, 2009, and references therein). We neglect consideration of $\mathrm{pH}<4.5$ because it is unlikely to occur over the remote Southern Ocean and these acidic conditions are unlikely to produce sulfate with a $\Delta^{17} \mathrm{O}$ consistent with observations, as sulfate formation by $\mathrm{O}_{3}$ will be suppressed. Cloud liquid water content is taken from GEOS-Chem, where it is calculated based on temperature, and cloud fraction from GEOS-Chem is scaled to Southern Ocean low cloud fraction observations (Eastman et al., 2011) while retaining its calculated vertical structure.

Nitrate model boundary conditions include concentrations of $\mathrm{NO}, \mathrm{NO}_{2}, \mathrm{HO}_{2}, \mathrm{O}_{3}, \mathrm{OH}, \mathrm{NO}_{3}$, VOCs (aldehydede, $\geq \mathrm{C}_{4}$ alkanes, $>\mathrm{C}_{2}$ aldhydes), DMS, and $\mathrm{N}_{2} \mathrm{O}_{5}$, as well as the photolysis rate of $\mathrm{NO}_{2}, \mathrm{NO}_{2}$ production rates by $\mathrm{RO}_{2}$ and $\mathrm{O}_{3}$, and aerosol surface area from GEOS-Chem. Physical parameters include air temperature and air density. When $\mathrm{BrO}$ is included, we assume a fixed concentration of $1 \mathrm{pmol} \mathrm{mol}^{-1}$.

\subsubsection{Monte Carlo approach}

The mean and standard deviation $\left(\sigma_{\mathrm{ox}}\right)$ of each monthly oxidant concentration is calculated based on the spatial variability across the region of interest (Southern Ocean for $\Delta^{17} \mathrm{O}\left(\mathrm{SO}_{4}{ }^{2-}\right)$; extratropical South America for $\left.\Delta^{17} \mathrm{O}\left(\mathrm{NO}_{3}{ }^{-}\right)\right)$in a present-day simulation using the GEOSChem global chemical transport model. Each iteration of the Monte Carlo model encompasses a year-long simulation of sulfate or nitrate chemistry. To span a large range of oxidant conditions, each oxidant is independently varied over $3 \sigma_{\text {ox }}$ to produce a wide Gaussian distribution of possible oxidant conditions (preserving the seasonal cycle), while all other boundary conditions are held constant (Sect. 5.4 justifies these assumption that other boundary conditions are held constant). In each iteration, the monthly mean oxidant concentrations from GEOS-Chem that serve as boundary conditions are scaled by a factor drawn from the $3 \sigma_{\text {ox }}$ distribution. For each simulation, the monthly and annual $\Delta^{17} \mathrm{O}\left(\mathrm{SO}_{4}{ }^{2-}\right)$ or $\Delta^{17} \mathrm{O}\left(\mathrm{NO}_{3}{ }^{-}\right)$is calculated. The box model is run repeatedly for approximately 10,000 simulations. We then search for pairs of simulations that match the observed change in $\Delta \Delta^{17} \mathrm{O}$. These pairs of simulations that match the $\Delta{ }^{17} \mathrm{O}$ observations provide the corresponding changes in annual mean oxidant concentrations required to match the ice core observations.

\subsubsection{Model limitations}

There is uncertainty in the assumed $\Delta^{17} \mathrm{O}$ of oxidants, the isotopic transfer from oxidants to products, and the chemical mechanisms in the box models, all of which could bias the calculation of $\Delta^{17} \mathrm{O}\left(\mathrm{NO}_{3}{ }^{-}\right)$or $\Delta^{17} \mathrm{O}\left(\mathrm{SO}_{4}{ }^{2-}\right)$ and concentrations in any given time period. Therefore, we focus on the magnitude of the change in $\Delta^{17} \mathrm{O}$ between time periods of interest, since the potential biases in the isotopic assumptions will be similar for each time period.

The above box model approach does not include coupling between oxidants as if they are in a photochemical box model. However, a photochemical box model will not provide an accurate representation of the relationships between oxidants on the time or spatial scales of interest because of the stiffness of the system as determined by the large difference in lifetimes between $\mathrm{OH}$ and $\mathrm{O}_{3}$ (Seinfeld and Pandis, 2006). Furthermore, the model does not allow for the mixing of sulfate or nitrate from multiple regions/sources that is likely representative of samples from WAIS Divide. While a global model would provide this, it would be less flexible for exploring how chemistry changes impact $\Delta^{17} \mathrm{O}$.

\section{WAIS Divide ice core observations}

Figure 2 shows the WAIS Divide ice core measurements of $\Delta^{17} \mathrm{O}\left(\mathrm{SO}_{4}{ }^{2-}\right), \Delta^{17} \mathrm{O}\left(\mathrm{NO}_{3}{ }^{-}\right)$, and $\delta^{15} \mathrm{~N}\left(\mathrm{NO}_{3}{ }^{-}\right)$. This record represents the first ice core record of $\Delta^{17} \mathrm{O}\left(\mathrm{NO}_{3}{ }^{-}\right)$ and $\Delta^{17} \mathrm{O}\left(\mathrm{SO}_{4}{ }^{2-}\right)$ sampled continuously over the past 2400 years.

$\Delta^{17} \mathrm{O}\left(\mathrm{SO}_{4}{ }^{2-}\right)$ is sampled at $7-15 \mathrm{~m}(27-68$ years $)$ resolution and varies between $1.8 \%$ and $3.7 \%$ over the entire record (Table 1 summarizes the sampling and isotopic measurement scheme). Prior to $1810 \mathrm{CE}, \Delta^{17} \mathrm{O}\left(\mathrm{SO}_{4}{ }^{2-}\right)$ is less than $2.8 \%$. From $1810-2005 \mathrm{CE}, \Delta^{17} \mathrm{O}\left(\mathrm{SO}_{4}{ }^{2-}\right)$ is greater than $3 \%$, with a maximum of $3.7 \%$ o between 1837 and $1880 \mathrm{CE}$. There is a $1.1 \%$ difference in the mean $\Delta^{17} \mathrm{O}\left(\mathrm{SO}_{4}{ }^{2-}\right)$ between the period prior to 1810 and that after 1837 . The 1810-1837 sample is excluded from this analysis because it is strongly influenced by the 1810 and Tambora volcanic eruptions (Kunasek et al., 2010). At the same time as the increase in $\Delta^{17} \mathrm{O}\left(\mathrm{SO}_{4}{ }^{2-}\right)$, there is a decrease in [MSA] and a slight, but not statistically significant, decrease in the $[\mathrm{MSA}] /\left[\mathrm{nsSSO}_{4}{ }^{2-}\right]$ ratio, although MSA records may be compromised by acid-driven mobilization of MSA around volcanic peaks. This is suggestive of a change in the chemistry of DMS oxidation at the same time as the observed change in the chemistry of $\mathrm{SO}_{2}$ oxidation. However, changes in the $[\mathrm{MSA}] /\left[\mathrm{nsSSO}_{4}{ }^{2-}\right]$ ratio could be driven by either temperature (influencing reaction rates), oxidant abundances $(\mathrm{OH})$.

$\Delta^{17} \mathrm{O}\left(\mathrm{NO}_{3}{ }^{-}\right)$is sampled at $1 \mathrm{~m}(1.8-4.8$ years $)$ resolution in the upper part of the core $(0-129 \mathrm{~m}$ depth, spanning $1521-2000 \mathrm{CE}$ ) and varies between $21.4 \%$ and $43.7 \%$. Figure 4 includes an expanded version of the $1 \mathrm{~m}$ resolution data from Fig. 2. Large intersample variability in the high-resolution $\Delta^{17} \mathrm{O}\left(\mathrm{NO}_{3}{ }^{-}\right)$record highlights its local nature, in that it represents the signal of $\mathrm{NO}_{\mathrm{x}}$ cycling and nitrate formation in the $\mathrm{NO}_{\mathrm{x}}$ source regions. Prior to $1586 \mathrm{CE}$, 


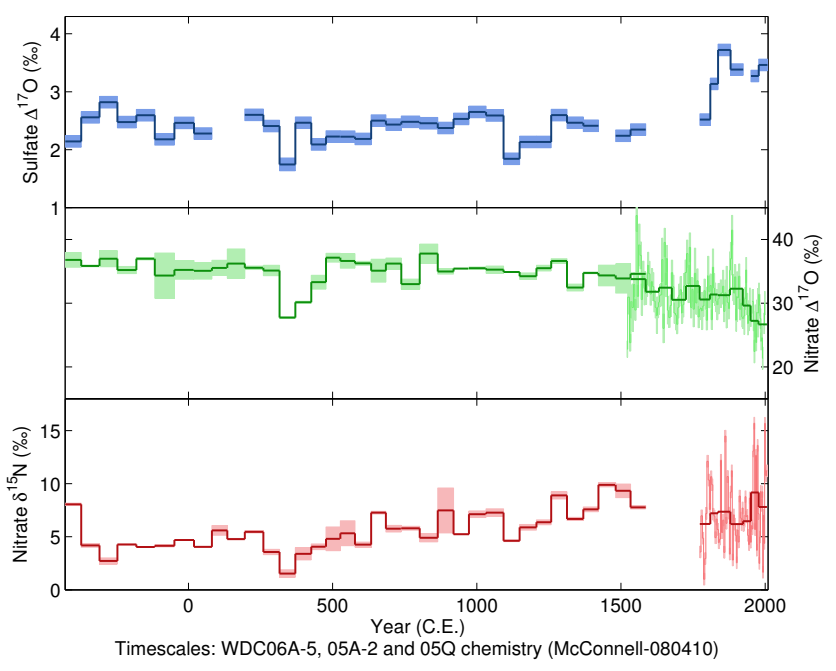

Figure 2. Measurements of $\Delta^{17} \mathrm{O}\left(\mathrm{SO}_{4}{ }^{2-}\right), \Delta^{17} \mathrm{O}\left(\mathrm{NO}_{3}{ }^{-}\right)$, and $\delta^{15} \mathrm{~N}\left(\mathrm{NO}_{3}{ }^{-}\right)$in the upper $577 \mathrm{~m}$ of the WAIS Divide ice core. Each horizontal line segment indicates the time interval of that sample. Shading indicates the measurement uncertainty based on the replicate analysis of standards $\left(\Delta^{17} \mathrm{O}\left(\mathrm{SO}_{4}{ }^{2-}\right)\right)$ or replicate sample measurements $\left(\Delta^{17} \mathrm{O}\left(\mathrm{NO}_{3}{ }^{-}\right), \delta^{15} \mathrm{~N}\left(\mathrm{NO}_{3}{ }^{-}\right)\right)$. The recent part of the nitrate isotope records are measured at $1 \mathrm{~m}$ resolution (see Fig. 4 for an expanded version of this record); the $1 \mathrm{~m}$ resolution measurements and their analytical uncertainty are shown in thin lines and shading and the thick lines through this portion of the $\Delta^{17} \mathrm{O}\left(\mathrm{NO}_{3}{ }^{-}\right)$and $\delta^{15} \mathrm{~N}\left(\mathrm{NO}_{3}{ }^{-}\right)$indicate the concentrationweighted isotopic values at the resolution of the $\Delta^{17} \mathrm{O}\left(\mathrm{SO}_{4}{ }^{2-}\right)$.

$\Delta^{17} \mathrm{O}\left(\mathrm{NO}_{3}{ }^{-}\right)$and $\delta^{15} \mathrm{~N}\left(\mathrm{NO}_{3}{ }^{-}\right)$are sampled at the same resolution as $\Delta^{17} \mathrm{O}\left(\mathrm{SO}_{4}{ }^{2-}\right)$. For the consideration of longterm trends and comparison to $\Delta^{17} \mathrm{O}\left(\mathrm{SO}_{4}{ }^{2-}\right)$, the $1 \mathrm{~m}$ resolution $\Delta^{17} \mathrm{O}\left(\mathrm{NO}_{3}{ }^{-}\right)$and $\delta^{15} \mathrm{~N}\left(\mathrm{NO}_{3}{ }^{-}\right)$records are smoothed by calculating a concentration-weighted average of the $1 \mathrm{~m}$ resolution nitrate isotope data to the temporal resolution of the $\Delta^{17} \mathrm{O}\left(\mathrm{SO}_{4}{ }^{2-}\right)$ measurements. Considering these lowresolution $\Delta^{17} \mathrm{O}\left(\mathrm{NO}_{3}{ }^{-}\right)$data, the maximum $\Delta^{17} \mathrm{O}\left(\mathrm{NO}_{3}{ }^{-}\right)$ of $37.8 \%$ occurs between 802 and $865 \mathrm{CE}$. The minimum of $26.7 \%$ occurs between 1977 and $2006 \mathrm{CE}$.

The ice core $\delta^{15} \mathrm{~N}\left(\mathrm{NO}_{3}{ }^{-}\right)$at $1 \mathrm{~m}$ resolution $(0-69.8 \mathrm{~m}$; 1774-2005 CE) varies between $1.0 \%$ (1787-1791 CE) and 15.7\% (1961-1964CE and 1998-2000CE). The lowresolution $\delta^{15} \mathrm{~N}\left(\mathrm{NO}_{3}{ }^{-}\right)$varies between $1.5 \%$ (316-370 CE) and $9.9 \%$ (1422-1481 CE), with a gradual upward trend since 370 CE. WAIS Divide $\left.\delta^{15} \mathrm{~N}_{\left(\mathrm{NO}_{3}\right.}{ }^{-}\right)$does not exhibit the large enrichments observed in East Antarctic sites and are similar in range to $\delta^{15} \mathrm{~N}\left(\mathrm{NO}_{3}{ }^{-}\right)$from Greenland summit ice cores $(-15.3-16.7 \%$ ) (Hastings et al. , 2004). The similarity to Greenland is likely due to comparable snow accumulation rates $\left(0.22-0.25 \mathrm{~m} \mathrm{a}^{-1}\right.$ water equivalent Fegyveresi et al., 2011) that limit the degree of postdepositional processing.

While there is significant variability in the low-resolution $\Delta^{17} \mathrm{O}$ data in the early part of the ice core record, the largest changes in both $\Delta^{17} \mathrm{O}\left(\mathrm{NO}_{3}{ }^{-}\right)$and $\Delta^{17} \mathrm{O}\left(\mathrm{SO}_{4}{ }^{2-}\right)$ occur in the period after $1800 \mathrm{CE}$. The maximum $\Delta^{17} \mathrm{O}\left(\mathrm{SO}_{4}{ }^{2-}\right)$ occurs in the sample spanning 1837-1880 CE with slightly lower values in the more recent samples, but the entire period $1837-2008$ has a higher $\Delta^{17} \mathrm{O}\left(\mathrm{SO}_{4}{ }^{2-}\right)$ than any earlier sample and the post-1837 samples are indistinguishable from each other within the laboratory precision $( \pm 0.3 \%$ ). In contrast to the step increase in $\Delta^{17} \mathrm{O}\left(\mathrm{SO}_{4}{ }^{2-}\right), \Delta^{17} \mathrm{O}\left(\mathrm{NO}_{3}{ }^{-}\right)$ gradually declines throughout the past 1000 years, with a more rapid decline beginning in the $1860 \mathrm{~s}$. While there is short-term variability in the $1 \mathrm{~m}$ resolution $\Delta^{17} \mathrm{O}\left(\mathrm{NO}_{3}{ }^{-}\right)$ record in the $1500 \mathrm{~s}$ that is comparable in magnitude to the recent decline in $\Delta^{17} \mathrm{O}\left(\mathrm{NO}_{3}{ }^{-}\right)$, on the 100 to 200 year timescale, the downward trend in $\Delta^{17} \mathrm{O}\left(\mathrm{NO}_{3}{ }^{-}\right)$between 1863 and $2000 \mathrm{CE}$ is statistically distinct from any other centennial trends in the $1 \mathrm{~m}$ resolution record (1521-2000 CE). Trends for all 100 year intervals with starting dates of 1521 $1859 \mathrm{CE}$ have a mean slope of $(-0.5 \pm 2.3) \%$ century $^{-1}$, while those trends starting after $1863 \mathrm{CE}$ have a mean slope of $(-6.7 \pm 0.8) \%$ century $^{-1}$. Similarly, the decrease in $\Delta^{17} \mathrm{O}\left(\mathrm{NO}_{3}{ }^{-}\right)$when averaged to the resolution of the $\Delta^{17} \mathrm{O}\left(\mathrm{SO}_{4}{ }^{2-}\right)$ data is $-5.6 \%$ from 1878 to $2000 \mathrm{CE}$.

Finally, there is a downward excursion in $\Delta^{17} \mathrm{O}\left(\mathrm{SO}_{4}{ }^{2-}\right)$, $\Delta^{17} \mathrm{O}\left(\mathrm{NO}_{3}{ }^{-}\right)$, and $\delta^{15} \mathrm{~N}\left(\mathrm{NO}_{3}{ }^{-}\right)$around the year $360 \mathrm{CE}$. The magnitude of the excursion in $\Delta^{17} \mathrm{O}\left(\mathrm{NO}_{3}{ }^{-}\right)$is comparable in magnitude to the changes observed between the $1860 \mathrm{~s}$ and the present day. There is no evidence of contamination in these samples and the deviation in both $\Delta^{17} \mathrm{O}\left(\mathrm{NO}_{3}{ }^{-}\right)$ and $\delta^{15} \mathrm{~N}\left(\mathrm{NO}_{3}{ }^{-}\right)$spans multiple samples. However, no other chemical tracers from the WAIS Divide ice core show a similar excursion. At this time, we do not attempt to explain the observed isotopic deviation around $360 \mathrm{CE}$ and instead focus on the sustained changes in $\Delta^{17} \mathrm{O}\left(\mathrm{SO}_{4}{ }^{2-}\right)$ and $\Delta^{17} \mathrm{O}\left(\mathrm{NO}_{3}{ }^{-}\right)$ between $1800 \mathrm{CE}$ and the present.

\section{Comparison of $\Delta^{17} \mathrm{O}$ to other ice core records}

To try to constrain the interpretation of the observed $\Delta^{17} \mathrm{O}$ changes, we compare the sulfate and nitrate isotopes to other ice core measurements (listed below in Sections 5.1 and 5.2) from WAIS Divide that are related to sulfate and nitrate formation (Figs. 3 and 4). These measurements are made using continuous-flow analysis (CFA) at DRI, following methods adapted from McConnell et al. (2002, 2007), providing centimeter-scale resolution, which are averaged to the resolution of the isotope records presented here.

The continuous-flow measurement of MSA has not been previously published, and is briefly described here. MSA was analyzed by pumping a portion of the degassed CFA melt stream to an electrospray ionization triple-quad mass spectrometer (ThermoFinnigan Quantum). The meltwater $\left(150 \mu \mathrm{L} \mathrm{min}^{-1}\right)$ was mixed with HPLC grade methanol $\left(50 \mu \mathrm{L} \mathrm{min}^{-1}\right)$ that was spiked with deuterated MSA as an internal standard $\left(\mathrm{CD}_{3} \mathrm{SO}_{3}{ }^{-}\right)$. MSA and deuterated MSA were 


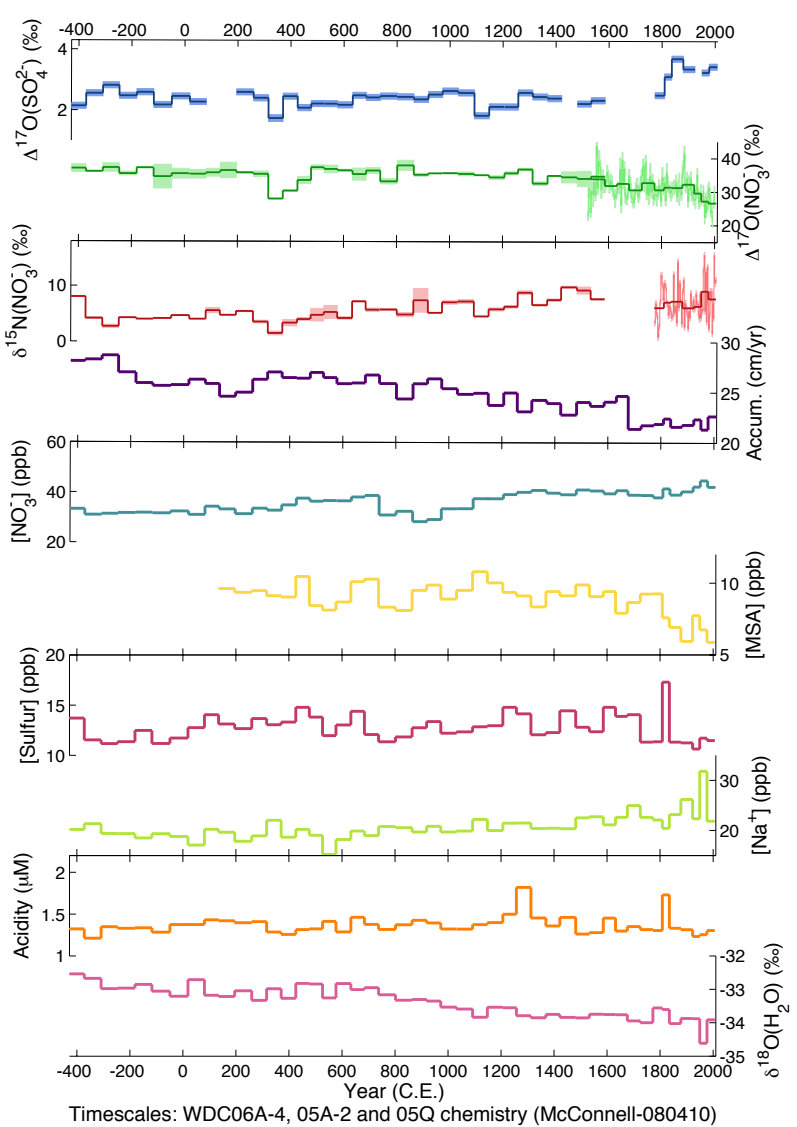

Figure 3. Low-resolution sulfate and nitrate isotopes compared to measurements of accumulation rate, nitrate concentration, MSA concentration, sulfur concentration, sodium concentration, acidity, and $\delta^{18} \mathrm{O}\left(\mathrm{H}_{2} \mathrm{O}\right)$ from the WDC06A core (except for $\mathrm{nssSO}_{4}{ }^{2-}$, from WDC05Q) averaged to the resolution of the sulfate isotope data.

detected in negative ion mode at the $95 / 80$ and $98 / 80 \mathrm{~m} / \mathrm{z}$ transitions (Saltzman et al., 2006). The internal standard was calibrated against aqueous MSA standards and the concentration of MSA in the ice core was determined from the ratio of the undeuterated and deuterated signals after minor blank corrections.

Records that come from the same core as the isotope record of interest are averaged with respect to depth. For comparison of measurements between different cores, highresolution data is divided into segments to match the resolution of the isotope data in the time domain and then averaged based on depth.

We calculate correlation coefficients and determine their statistical significance using the $p$ value $(\leq 0.05)$ with the number of degrees of freedom adjusted based upon the autocorrelation in the time series (Bretherton et al., 1999).

\section{$5.1 \Delta^{17} \mathrm{O}\left(\mathrm{SO}_{4}{ }^{2-}\right)$ comparison}

Measurements of ice core acidity (Fig. 3) or calculated $\left[\mathrm{H}^{+}\right]$ based on sulfate, nitrate, and ammonium concentrations provide the best available insight into possible changes in cloud water $\mathrm{pH}$, which impacts $\mathrm{S}(\mathrm{IV})$ speciation and the relative importance of oxidation by $\mathrm{O}_{3}$ and $\mathrm{H}_{2} \mathrm{O}_{2}$. However, the acidity record shows little variability, and $\Delta^{17} \mathrm{O}\left(\mathrm{SO}_{4}{ }^{2-}\right)$ does not correlate with either ice core acidity or $\left[\mathrm{H}^{+}\right]$, making it unlikely that a change in cloud water $\mathrm{pH}$ could explain the observed change in $\Delta^{17} \mathrm{O}\left(\mathrm{SO}_{4}{ }^{2-}\right)$.

Similarly, $\Delta^{17} \mathrm{O}\left(\mathrm{SO}_{4}{ }^{2-}\right)$ shows no correlation with concentrations of transition metals (Fe or Mn) (Fig. 3) that may impact the aqueous-phase oxidation of S(IV) by $\mathrm{O}_{2}$. Furthermore, CTM studies indicate that metal-catalyzed oxidation of $\mathrm{S}(\mathrm{IV})$ is a minor sulfate production pathway in the extratropical Southern Hemisphere (Alexander et al., 2009; Sofen et al., 2011). The lack of a relationship between $\Delta^{17} \mathrm{O}\left(\mathrm{SO}_{4}{ }^{2-}\right)$ and transition metal concentrations or acidity is notable, as it has been demonstrated that metal-catalyzed oxidation of $\mathrm{S}(\mathrm{IV})$ by $\mathrm{O}_{2}$ is important for describing the observed variability of $\Delta^{17} \mathrm{O}\left(\mathrm{SO}_{4}{ }^{2-}\right)$ in a Greenland ice core over the same time period (Sofen et al., 2011).

$\Delta^{17} \mathrm{O}\left(\mathrm{SO}_{4}{ }^{2-}\right)$ does not show a statistically significant correlation with $\left[\mathrm{Na}^{+}\right]$, a proxy for sea salt (Fig. 3). Sea-salt sulfate represents $15-22 \%$ of the total sulfate in these samples. However, $\left[\mathrm{Na}^{+}\right]$does not change in the early 1800 s in a similar way to $\Delta^{17} \mathrm{O}\left(\mathrm{SO}_{4}{ }^{2-}\right)$. The step change in $\Delta^{17} \mathrm{O}\left(\mathrm{SO}_{4}{ }^{2-}\right)$ is present in the record prior to correction for sea-salt sulfate.

$\Delta^{17} \mathrm{O}\left(\mathrm{SO}_{4}{ }^{2-}\right)$ and sulfur concentrations (Fig. 3) are not correlated. This suggests that variability in $\Delta^{17} \mathrm{O}\left(\mathrm{SO}_{4}{ }^{2-}\right)$ is not controlled by changes in the magnitude of the sulfur source or the sulfur source region, as a change in the source region that impacted sulfate formation would likely be accompanied by a change in the amount of sulfate transported to WAIS Divide.

Hydrogen peroxide is the one oxidant species that can be directly measured in ice cores. Oxidation of S(IV) by $\mathrm{H}_{2} \mathrm{O}_{2}$ is thought to be the dominant sulfate formation pathway globally. Since $\Delta^{17} \mathrm{O}\left(\mathrm{SO}_{4}{ }^{2-}\right)$ of sulfate formed by $\mathrm{H}_{2} \mathrm{O}_{2}$ is only $0.65 \%$, an increase in $\mathrm{H}_{2} \mathrm{O}_{2}$ in the southern high latitudes should decrease $\Delta^{17} \mathrm{O}\left(\mathrm{SO}_{4}{ }^{2-}\right)$ at WAIS Divide. We find that the WAIS Divide $\Delta^{17} \mathrm{O}\left(\mathrm{SO}_{4}{ }^{2-}\right)$ and $\left[\mathrm{H}_{2} \mathrm{O}_{2}\right]$ records (Fig. 3) are not correlated. Ice core $\left[\mathrm{H}_{2} \mathrm{O}_{2}\right]$ does not significantly change during the early 19 th century when $\Delta^{17} \mathrm{O}\left(\mathrm{SO}_{4}{ }^{2-}\right)$ undergoes a step increase. However, $\mathrm{H}_{2} \mathrm{O}_{2}$ increases by approximately $60 \%$ in the period after $1837 \mathrm{CE}$, when $\Delta^{17} \mathrm{O}\left(\mathrm{SO}_{4}{ }^{2-}\right)$ remains relatively constant.

There is no available ice core proxy for fractional cloud cover or cloud liquid water content, both of which impact sulfate formation and thus $\Delta^{17} \mathrm{O}\left(\mathrm{SO}_{4}{ }^{2-}\right)$. We assume no change in these parameters based on the fact that climate has been relatively stable over this time period, as indicated by temperature proxies (e.g., $\delta^{18} \mathrm{O}\left(\mathrm{H}_{2} \mathrm{O}\right)$ ). 


\section{$5.2 \quad \Delta^{17} \mathrm{O}\left(\mathrm{NO}_{3}{ }^{-}\right)$comparison}

Due to the fact that $\mathrm{H}_{2} \mathrm{O}_{2}$ forms via the self-reaction of $\mathrm{HO}_{2}$, we would expect the large-scale increase in $\mathrm{H}_{2} \mathrm{O}_{2}$ to be reflected in a decrease in $\Delta^{17} \mathrm{O}\left(\mathrm{NO}_{3}{ }^{-}\right)$due to the increased importance of $\mathrm{HO}_{2}$ in $\mathrm{NO}_{\mathrm{x}}$ cycling as long as the relative increase in $x\left(\mathrm{HO}_{2}\right)$, where $x$ represents the mole fraction, is greater than the increase in $x\left(\mathrm{O}_{3}\right)$. We would expect a larger change in $\Delta^{17} \mathrm{O}\left(\mathrm{NO}_{3}{ }^{-}\right)$than $\mathrm{H}_{2} \mathrm{O}_{2}$ if organic peroxides were also increasing, since $\mathrm{H}_{2} \mathrm{O}_{2}$ may not be influenced as strongly by changes in organic peroxide concentration $x\left(\mathrm{RO}_{2}\right)$ as it is by $\mathrm{HO}_{2}$. However, this may be alleviated by a simultaneous increase in $x\left(\mathrm{O}_{3}\right)$, since $\Delta^{17} \mathrm{O}\left(\mathrm{NO}_{3}{ }^{-}\right)$reflects $x\left(\mathrm{O}_{3}\right) / x\left(\mathrm{RO}_{2}\right)$. If $\Delta^{17} \mathrm{O}\left(\mathrm{NO}_{3}{ }^{-}\right)$is influenced by local Antarctic boundary layer chemistry, we expect $\Delta^{17} \mathrm{O}\left(\mathrm{NO}_{3}{ }^{-}\right)$ to decrease at a more rapid rate beginning in the 1970s due to the impacts of the recent increase in UV flux on $\mathrm{H}_{2} \mathrm{O}_{2}$ (Lamarque et al., 2011).

Indeed, $\left[\mathrm{H}_{2} \mathrm{O}_{2}\right]$ (Fig. 4) is anti-correlated with the $1 \mathrm{~m}$ resolution $\Delta^{17} \mathrm{O}\left(\mathrm{NO}_{3}{ }^{-}\right)$between 1521 and $2000 \mathrm{CE}(R=$ -0.36 ), consistent with an increase in the importance of $\mathrm{RO}_{2}$ in $\mathrm{NO}_{\mathrm{x}}$ cycling. The temporal resolution in $\Delta^{17} \mathrm{O}\left(\mathrm{NO}_{3}{ }^{-}\right)$ observations is not high enough to test whether the ozone hole impacts $\Delta^{17} \mathrm{O}\left(\mathrm{NO}_{3}{ }^{-}\right)$through snowpack photodenitrification or the oxidizing capacity of the Antarctic boundary layer. The trend in $\Delta^{17} \mathrm{O}\left(\mathrm{NO}_{3}{ }^{-}\right)$over the last thirty years $\left((-4 \pm 4) \%_{o}\right.$ century $\left.^{-1}\right)$ is indistinguishable from that of the last 100 years $\left((-5 \pm 1) \%\right.$ century $\left.^{-1}\right)$, further suggesting that postdepositional loss does not have a strong influence on ice core nitrate or its isotopes at WAIS Divide.

Ice core observations of [MSA] (Fig. 3), indicative of DMS emissions, show a downward trend over the past 1800 years, but the correlation with the low-resolution $\Delta^{17} \mathrm{O}\left(\mathrm{NO}_{3}{ }^{-}\right)$is not significant. A reduction in DMS would diminish the fraction of nitrate formed through the hydrogen abstraction pathway, reducing the $\Delta^{17} \mathrm{O}\left(\mathrm{NO}_{3}{ }^{-}\right)$. Therefore, the trend in MSA is consistent with the long-term trend in $\Delta^{17} \mathrm{O}\left(\mathrm{NO}_{3}{ }^{-}\right)$. However, there are a number of complicating factors in the interpretation of the MSA record. First, it assumes a constant relationship between DMS and MSA concentrations in the atmosphere, which could vary with changing oxidants. Second, MSA is also sensitive to postdepositional loss from the snowpack through volatilization (Weller et al., 2004), and the downward trend in MSA is consistent with increasing postdepositional processing as accumulation declines (see Fig. 3; as is the case for $\Delta^{17} \mathrm{O}\left(\mathrm{NO}_{3}{ }^{-}\right.$) and $\delta^{15} \mathrm{~N}\left(\mathrm{NO}_{3}{ }^{-}\right)$), although it has been argued that postdepositional loss of MSA is insignificant when snow accumulation is higher than $0.1 \mathrm{~m} \mathrm{a}^{-1}$ water equivalent (Weller et al., 2004). Finally, the past 150 years in the MSA record do not show a change in [MSA] akin to that observed in $\Delta^{17} \mathrm{O}\left(\mathrm{NO}_{3}{ }^{-}\right)$(Fig. 4) and the two records are not significantly correlated over this time period (using $1 \mathrm{~m}$ resolution measurements).

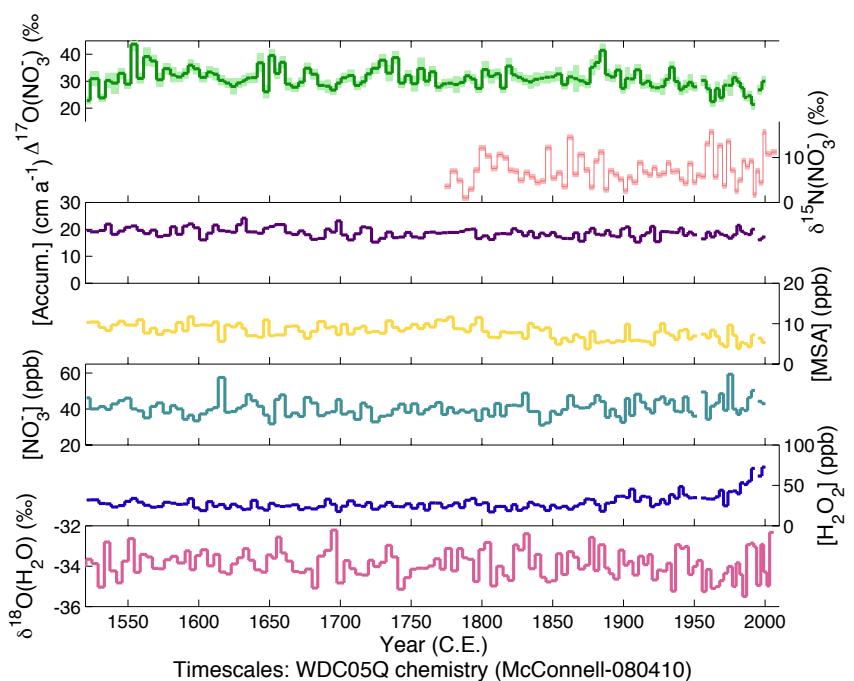

Figure 4. $1 \mathrm{~m}$ resolution $\Delta^{17} \mathrm{O}\left(\mathrm{NO}_{3}{ }^{-}\right)$(WDC05Q core) and $\delta^{15} \mathrm{~N}\left(\mathrm{NO}_{3}{ }^{-}\right)$(WDC05A) compared to measurements of accumulation rate (WDC05Q), MSA concentration (WDC06A), nitrate concentration (WDC06A), and hydrogen peroxide concentration (WDC05Q), averaged to the resolution of the $\Delta^{17} \mathrm{O}\left(\mathrm{NO}_{3}{ }^{-}\right)$data. $\delta^{18} \mathrm{O}\left(\mathrm{H}_{2} \mathrm{O}\right)$ is shown at the resolution of the $\delta^{15} \mathrm{~N}\left(\mathrm{NO}_{3}{ }^{-}\right)$data, as they were both measured at $1 \mathrm{~m}$ resolution on the same core (WDC05A).

The $\Delta^{17} \mathrm{O}\left(\mathrm{NO}_{3}{ }^{-}\right)$is not correlated with nitrate concentrations (Fig. 4) at $1 \mathrm{~m}$ resolution between $1521 \mathrm{CE}$ and present, and there is little trend in the concentration of nitrate over the past 200 years. This, in conjunction with the absence of large changes in $\left[\mathrm{NO}_{3}{ }^{-}\right]$or $\delta^{15} \mathrm{~N}\left(\mathrm{NO}_{3}{ }^{-}\right)$all suggest that sources of nitrate to WAIS Divide have likely remained constant over this period, as a major shift in source regions would likely be accompanied by a change in the amount of nitrate transported to WAIS Divide and possibly the isotopic composition.

In addition to nitrate that forms at lower latitudes, $\mathrm{NO}_{\mathrm{x}}$ emitted in mid-latitude continental regions could be transported to Antarctica via the reservoir molecule peroxyacetyl nitrate (PAN), which then thermally decomposes, releasing $\mathrm{NO}_{\mathrm{x}}$, which will then be oxidized to $\mathrm{NO}_{3}{ }^{-}$in the local Antarctic atmosphere. While there is no proxy for PAN, mean PAN concentration of $(13 \pm 7) \mathrm{pmol} \mathrm{mol}^{-1}$ with a slow decomposition rate of $0.05 \mathrm{pmol} \mathrm{mol}^{-1} \mathrm{~h}^{-1}$ are found at Neumayer (Jacobi et al., 2000). More recent measurements at Neumayer suggest that PAN varies between a net sink (spring) and a net source (summer) of $\mathrm{NO}_{\mathrm{x}}$ with PAN loss rates of between 0.17 and $0.58 \mathrm{pmol} \mathrm{mol}^{-1} \mathrm{~h}^{-1}$ (Jones et al., 2011). PAN concentrations and loss rates are an order of magnitude lower than in the Arctic (Beine and Krognes, 2000), suggesting that PAN decomposition is an unimportant factor in WAIS Divide nitrate formation. Furthermore, while atmospheric PAN concentrations can be higher than inorganic nitrogen species during winter, snowpack nitrate concentrations correlate with inorganic reactive nitrogen (Jones 
et al., 2011), likely due to the longer lifetime to deposition of organic nitrate than inorganic nitrate (Wolff et al., 2008).

Finally, stratospheric denitrification is a potential source of high- $\Delta{ }^{17} \mathrm{O}$ nitrate to Antarctica, although its magnitude in West Antarctica is unknown. While it may impact the magnitude of the average $\Delta^{17} \mathrm{O}\left(\mathrm{NO}_{3}{ }^{-}\right)$observed in the WAIS Divide ice core, there is no reason to expect systematic changes in the polar stratospheric nitrate flux prior to the formation of the ozone hole in the 1970s. Furthermore, the lower elevation of West Antarctica likely means that stratospheric deposition is less important than on the East Antarctic Plateau.

\subsection{Influence of postdepositional processing on $\Delta^{17} \mathrm{O}\left(\mathrm{NO}_{3}{ }^{-}\right)$}

The magnitude of nitrate postdepositional processing impacts the extent to which $\Delta^{17} \mathrm{O}\left(\mathrm{NO}_{3}{ }^{-}\right)$reflects regional oxidants from where the $\mathrm{NO}_{3}{ }^{-}$is originally formed versus local oxidants from snowpack $\mathrm{NO}_{\mathrm{x}}$ being oxidized back to $\mathrm{NO}_{3}{ }^{-}$in the Antarctic boundary layer. The 2400 year $\delta^{15} \mathrm{~N}\left(\mathrm{NO}_{3}{ }^{-}\right)$record is negatively correlated with snow accumulation rate (Fegyveresi et al., 2011) $(R=-0.62)$ and positively correlated with $\left[\mathrm{NO}_{3}{ }^{-}\right](R=0.58$; Fig. 3). Similarly, at low resolution, $\delta^{18} \mathrm{O}\left(\mathrm{H}_{2} \mathrm{O}\right)$ (Fig. 3), a temperature proxy, is anti-correlated with $\delta^{15} \mathrm{~N}\left(\mathrm{NO}_{3}{ }^{-}\right)(R=-0.63)$ over the entire 2400 year record. However, $\Delta^{17} \mathrm{O}\left(\mathrm{NO}_{3}{ }^{-}\right)$and $\delta^{15} \mathrm{~N}\left(\mathrm{NO}_{3}{ }^{-}\right)$are not correlated with each other. The correlations between $\delta^{15} \mathrm{~N}\left(\mathrm{NO}_{3}{ }^{-}\right),\left[\mathrm{NO}_{3}{ }^{-}\right]$, snow accumulation, and temperature suggests that on long timescales some degree of postdepositional processing of snowpack $\mathrm{NO}_{3}{ }^{-}$is occurring at WAIS Divide. Increasing postdepositional processing due to the long-term decline in snow accumulation over the past 2000 years is likely responsible for the gradual downward trend in $\Delta^{17} \mathrm{O}\left(\mathrm{NO}_{3}{ }^{-}\right)$and upward trend in $\delta^{15} \mathrm{~N}\left(\mathrm{NO}_{3}{ }^{-}\right)$. However, the magnitude of the $\delta^{15} \mathrm{~N}\left(\mathrm{NO}_{3}{ }^{-}\right)$ values $(1.0-15.7 \%$ ) is comparable to Greenland snowpack nitrate (Hastings et al. , 2004, 2009) and only slightly enriched compared to $\mathrm{NO}_{\mathrm{x}}$ emissions and mid-latitude aerosol observations (Morin et al., 2009; Felix et al., 2012), suggesting that the majority of nitrate is well preserved in the snowpack. This is in contrast to East Antarctica where snowpack $\delta^{15} \mathrm{~N}\left(\mathrm{NO}_{3}{ }^{-}\right)$enrichments on the order of $300 \%$ o are observed. A flux of $\mathrm{NO}_{\mathrm{x}}$ emitted from East Antarctic snowpack and transported to WAIS Divide could also contribute to the low $\delta^{15} \mathrm{~N}_{\left(\mathrm{NO}_{3}{ }^{-}\right)}$) values observed at WAIS Di-

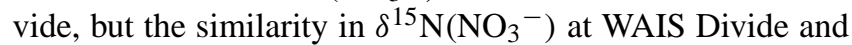
Greenland summit sites with comparable snow accumulation rate suggest that this is not the case. Furthermore, while the $1 \mathrm{~m}$ resolution $\delta^{15} \mathrm{~N}\left(\mathrm{NO}_{3}{ }^{-}\right)$between 1774 and $2008 \mathrm{CE}$ is anti-correlated with the snow accumulation rate (Fig. 4; $R=-0.35)$, the $1 \mathrm{~m}$ resolution $\Delta^{17} \mathrm{O}\left(\mathrm{NO}_{3}{ }^{-}\right)$is not correlated with snow accumulation, $\left[\mathrm{NO}_{3}{ }^{-}\right]$, or $\delta^{15} \mathrm{~N}\left(\mathrm{NO}_{3}{ }^{-}\right)$ over the period 1521-2000 CE, suggesting that postdepositional processing does not have a controlling influence on higher frequency variability, such as the downward trend in $\Delta^{17} \mathrm{O}\left(\mathrm{NO}_{3}{ }^{-}\right)$since the 1860 s.

\subsection{Non-oxidant influences on $\Delta^{17} \mathrm{O}$}

The above comparisons between sulfate and nitrate isotopes and other tracers from the WAIS Divide ice cores include several related to the non-oxidant influences on $\Delta^{17} \mathrm{O}$. These measurements include ice core acidity (proxy for cloud water $\mathrm{pH}$ ) (Pasteris et al., 2012), [Mn] and [Fe] (impacting metalcatalyzed $\mathrm{S}(\mathrm{IV})$ oxidation by $\mathrm{O}_{2}$ ), $\left[\mathrm{Na}^{+}\right]$(proxy for seasalt aerosol), [MSA] (a proxy for DMS), [S] and $\left[\mathrm{SO}_{4}{ }^{2-}\right]$ (proxy for sulfate sources and sulfate aerosol abundance), $\left[\mathrm{NO}_{3}{ }^{-}\right]$(proxy for nitrate sources and nitrate aerosol abundance), snow accumulation rate (related to postdepositional loss of nitrate), and $\delta^{18} \mathrm{O}\left(\mathrm{H}_{2} \mathrm{O}\right)$ (temperature proxy). We find that most of these records either show no significant correlation with either nitrate or sulfate isotopes or are correlated only on long timescales (the entire 2400 year record) with the low-resolution isotopes. While non-oxidant factors may contribute to the long-term variability in the WAIS Divide sulfate and nitrate isotopes, visually and statistically, none of the records representing non-oxidant factors exhibit changes similar to the observed changes in $\Delta^{17} \mathrm{O}\left(\mathrm{NO}_{3}{ }^{-}\right)$ and $\Delta^{17} \mathrm{O}\left(\mathrm{SO}_{4}{ }^{2-}\right)$ over the past 200 years. This analysis suggests that variability in oxidant concentrations is the only possible explanation for the observed $1.1 \%$ increase in $\Delta^{17} \mathrm{O}\left(\mathrm{SO}_{4}{ }^{2-}\right)$ in the early 19 th century and the $5.6 \%$ decrease in $\Delta^{17} \mathrm{O}\left(\mathrm{NO}_{3}{ }^{-}\right)$since the mid-19th century.

\section{Monte Carlo box models of oxidant influences on $\Delta^{17} \mathbf{O}$}

To consider what changes in oxidants could cause the observed changes in $\Delta^{17} \mathrm{O}$ since $1800 \mathrm{CE}$, we employ Monte Carlo box model simulations of sulfate and nitrate chemistry to investigate the magnitude of the oxidant changes implied in two time periods: the observed $1.1 \%$ increase in $\Delta^{17} \mathrm{O}\left(\mathrm{SO}_{4}{ }^{2-}\right)$ in the early 19 th century and $5.6 \%$ decrease in $\Delta^{17} \mathrm{O}\left(\mathrm{NO}_{3}{ }^{-}\right)$between the 1860 s and the present day. Based on the evidence of little postdepositional processing at WAIS Divide, $\mathrm{NO}_{\mathrm{x}}$ emissions and nitrate formation likely occur over Southern Hemisphere extratropical continental regions. The model uses boundary conditions from the extratropical South American boundary layer to calculate nitrate formation, reflecting the likely dominant source region for Antarctic nitrate (Lee et al., 2014). The sulfate box model uses boundary conditions from the Southern Ocean marine boundary layer (MBL), reflecting the dominant source region for Antarctic sulfate (Patris et al., 2000; Cosme et al., 2005; Sofen et al., 2011). 

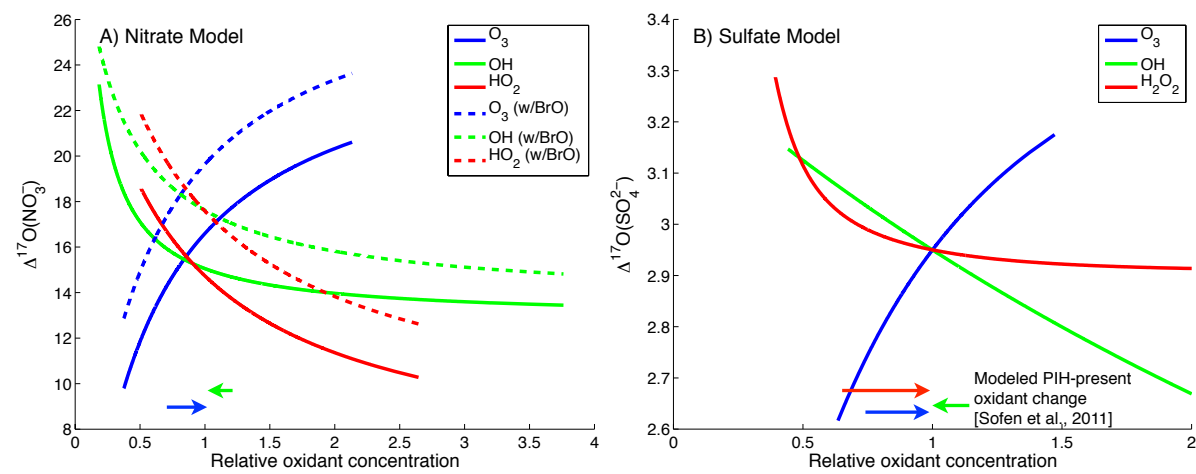

Figure 5. Sensitivity of (A) $\Delta^{17} \mathrm{O}\left(\mathrm{NO}_{3}{ }^{-}\right)$and (B) $\Delta^{17} \mathrm{O}\left(\mathrm{SO}_{4}{ }^{2-}\right)$ to variations in each oxidant, normalized to the mean oxidant concentrations $(=1.0)$ of the present-day South American and Southern Ocean boundary layers, respectively. Dashed lines indicate results when $1 \mathrm{pmol} \mathrm{mol}^{-1} \mathrm{BrO}$ is include as both an oxidant of $\mathrm{NO}$ in $\mathrm{NO}_{\mathrm{x}}$ cycling and as an oxidant of $\mathrm{NO}_{2}$, which leads to nitrate formation via the hydrolysis of $\mathrm{BrONO}_{2}$. Arrows at the bottom indicate the fractional change in oxidant abundances over the Southern Ocean between preindustrial Holocene and present-day chemical transport model simulations (Sofen et al., 2011) for reference.

\subsection{Model $\Delta^{17}$ O-oxidant sensitivity}

The box models are first used to assess the sensitivity of $\Delta^{17} \mathrm{O}\left(\mathrm{SO}_{4}{ }^{2-}\right)$ and $\Delta^{17} \mathrm{O}\left(\mathrm{NO}_{3}{ }^{-}\right)$to changes in the concentration of each oxidant. Figure 5 shows the sensitivity of $\Delta^{17} \mathrm{O}\left(\mathrm{SO}_{4}{ }^{2-}\right)$ and $\Delta^{17} \mathrm{O}\left(\mathrm{NO}_{3}{ }^{-}\right)$to a relative change in the concentration of each oxidant normalized to the mean conditions extracted from GEOS-Chem for the boundary conditions described above (Southern Ocean and South American boundary layers, respectively) (Sofen et al., 2011). The slope of each curve represents the response of $\Delta^{17} \mathrm{O}$ to a change in a particular oxidant.

$\Delta^{17} \mathrm{O}\left(\mathrm{SO}_{4}{ }^{2-}\right)$ is sensitive to changes in $\mathrm{O}_{3}, \mathrm{OH}$, and $\mathrm{H}_{2} \mathrm{O}_{2}$ over the Southern Ocean, with $\Delta^{17} \mathrm{O}\left(\mathrm{SO}_{4}{ }^{2-}\right)$ increasing with increasing $\mathrm{O}_{3}$ and increasing with decreasing $\mathrm{OH}$ or $\mathrm{H}_{2} \mathrm{O}_{2} \cdot \Delta^{17} \mathrm{O}\left(\mathrm{SO}_{4}{ }^{2-}\right)$ becomes insensitive to changes in $\mathrm{H}_{2} \mathrm{O}_{2}$ at $\mathrm{H}_{2} \mathrm{O}_{2}$ concentrations greater than or equal to those of the present-day Southern Ocean marine boundary layer. The sensitivity of $\Delta^{17} \mathrm{O}\left(\mathrm{SO}_{4}{ }^{2-}\right)$ to $\mathrm{H}_{2} \mathrm{O}_{2}$ and $\mathrm{O}_{3}$, as measured by the slope in Fig. 5, varies with their abundances, with higher sensitivity at lower $x\left(\mathrm{H}_{2} \mathrm{O}_{2}\right)$ and $x\left(\mathrm{O}_{3}\right)$, respectively. The sensitivity of $\Delta^{17} \mathrm{O}\left(\mathrm{SO}_{4}{ }^{2-}\right)$ to $x(O H)$ is nearly linear over the range of $\mathrm{OH}$ concentrations considered.

$\Delta^{17} \mathrm{O}\left(\mathrm{NO}_{3}{ }^{-}\right)$is most sensitive to $\mathrm{O}_{3}$ and $\mathrm{RO}_{2}$, because $\frac{2}{3}$ of the $\Delta^{17} \mathrm{O}$ of nitrate is determined during the $\mathrm{NO}_{\mathrm{x}}-$ cycling step. $\Delta^{17} \mathrm{O}\left(\mathrm{NO}_{3}{ }^{-}\right)$increases with increasing $\mathrm{O}_{3}$ and decreases with increasing $\mathrm{RO}_{2}$. Changes in $\Delta^{17} \mathrm{O}\left(\mathrm{NO}_{3}{ }^{-}\right)$ mainly reflect changes in $x\left(\mathrm{O}_{3}\right) / x\left(\mathrm{RO}_{2}\right)$; that is, the variability in $\Delta^{17} \mathrm{O}\left(\mathrm{NO}_{3}{ }^{-}\right)$is dominated by the $\mathrm{NO}_{\mathrm{x}}$-cycling step. Except at extremely low $\mathrm{OH}$ concentrations, $\Delta^{17} \mathrm{O}\left(\mathrm{NO}_{3}{ }^{-}\right)$ only weakly depends on $x(\mathrm{OH})$ because $\mathrm{NO}_{2}+\mathrm{OH}$ is always the dominant nitrate formation pathway during daytime. Including $\mathrm{BrO}$ in $\mathrm{NO}_{\mathrm{x}}$ cycling and the oxidation of $\mathrm{NO}_{2}$ to $\mathrm{NO}_{3}{ }^{-}$via the hydrolysis of $\mathrm{BrONO}_{2}$ changes the sensitivity of $\Delta^{17} \mathrm{O}\left(\mathrm{NO}_{3}{ }^{-}\right)$to each of the oxidants (dashed lines; Fig. 5). BrO oxidation of $\mathrm{NO}$ leads to an overall upward shift in $\Delta^{17} \mathrm{O}\left(\mathrm{NO}_{3}{ }^{-}\right)$, as well as increasing the sensitivity of $\Delta^{17} \mathrm{O}\left(\mathrm{NO}_{3}{ }^{-}\right)$to changes in $\mathrm{OH}$ concentrations by providing a competing daytime $\mathrm{NO}_{2}$-oxidation pathway. Increasing $x(\mathrm{BrO})$ further increases the sensitivity of $\Delta^{17} \mathrm{O}\left(\mathrm{NO}_{3}{ }^{-}\right)$to $\mathrm{OH}$. However, note that with or without bromine chemistry, the box model underestimates the mean $\Delta^{17} \mathrm{O}\left(\mathrm{NO}_{3}{ }^{-}\right)$of the observations when we assume $\Delta^{17} \mathrm{O}\left(\mathrm{O}_{3}\right)$ is $25 \%$.

These initial model results provide a qualitative explanation for how the change in $\Delta^{17} \mathrm{O}\left(\mathrm{SO}_{4}{ }^{2-}\right)$ and $\Delta^{17} \mathrm{O}\left(\mathrm{NO}_{3}{ }^{-}\right)$ can have opposite signs between $1800 \mathrm{CE}$ and the present given likely increases in both $\mathrm{O}_{3}$ and $\mathrm{H}_{2} \mathrm{O}_{2}$ (and therefore $\mathrm{RO}_{2}$ ), and a small decrease in $\mathrm{OH}$ in the extratropical Southern Hemisphere. In sum, the increase in $\Delta^{17} \mathrm{O}\left(\mathrm{SO}_{4}{ }^{2-}\right)$ and decrease in $\Delta^{17} \mathrm{O}\left(\mathrm{NO}_{3}{ }^{-}\right)$can be explained by an increase in the $x\left(\mathrm{O}_{3}\right) / x(\mathrm{OH})$ ratio over the Southern Ocean and a decrease in the $x\left(\mathrm{O}_{3}\right) / x\left(\mathrm{RO}_{2}\right)$ ratio over Southern Hemisphere extratropical continents respectively, which is qualitatively consistent with our expectations.

\subsection{Oxidant changes suggested by $\Delta^{17} \mathrm{O}\left(\mathrm{NO}_{3}{ }^{-}\right)$}

The nitrate Monte Carlo box model simulations indicate that to match the observed decrease in $\Delta^{17} \mathrm{O}\left(\mathrm{NO}_{3}{ }^{-}\right)$, assuming no change $(\leq 5 \%)$ in Southern Hemisphere extratropical $x(\mathrm{OH})$ between the $1860 \mathrm{~s}$ and $2000 \mathrm{CE}$, the $x\left(\mathrm{O}_{3}\right) / x\left(\mathrm{RO}_{2}\right)$ ratio must decrease by $60-90 \%$ in the $\mathrm{NO}_{3}{ }^{-}$formation region. As shown in Fig. 6b, $x\left(\mathrm{O}_{3}\right)$ can increase by up to $80 \%$ and $x\left(\mathrm{RO}_{2}\right)$ must increase by $130-350 \%$ to be consistent with the $\Delta^{17} \mathrm{O}\left(\mathrm{NO}_{3}{ }^{-}\right)$observations. If $x(\mathrm{OH})$ decreases by $33 \%$ (the lower bound of CTM studies), $x\left(\mathrm{O}_{3}\right) / x\left(\mathrm{RO}_{2}\right)$ must decrease by an even larger amount ( -62 to $-94 \%)$. An increase in $x\left(\mathrm{O}_{3}\right) / x\left(\mathrm{RO}_{2}\right)$ is only possible if $x(\mathrm{OH})$ increases by $>250 \%$, which is highly unlikely over this time period due to increasing $\mathrm{CH}_{4}$, which is a major sink of $\mathrm{OH}$. If we assume a $25-63 \%$ increase in $x\left(\mathrm{O}_{3}\right)$ since the preindustrial period based on global models and no change in 


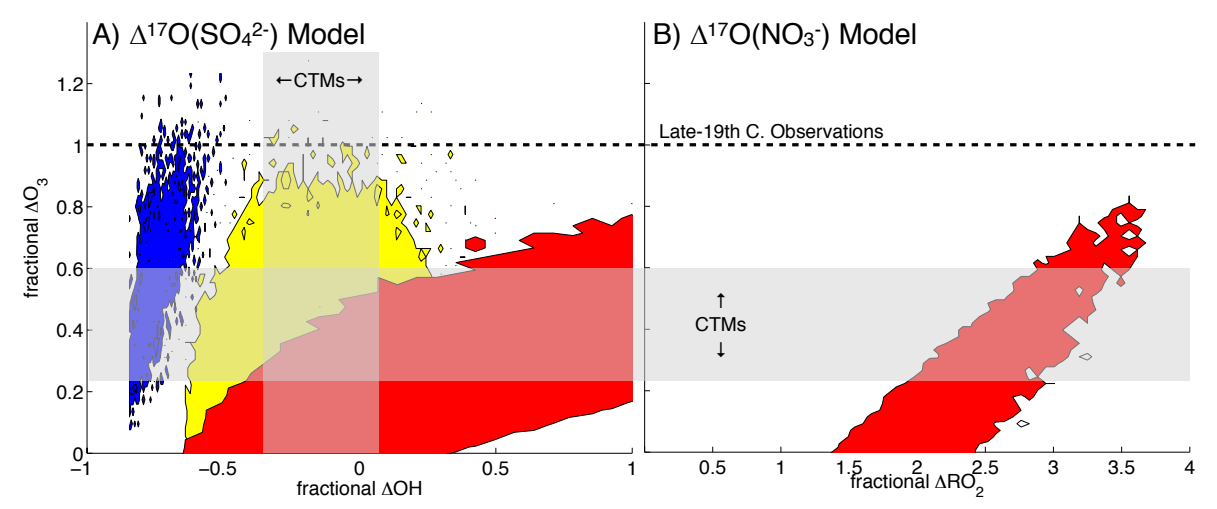

Figure 6. Envelope of fractional oxidant changes from Monte Carlo simulations matching the observed changes in $\Delta^{17} \mathrm{O}$. (A) Change in $\left[\mathrm{O}_{3}\right]$ and $[\mathrm{OH}]$ associated with the early 19 th century increase in $\Delta^{17} \mathrm{O}\left(\mathrm{SO}_{4}{ }^{2-}\right)$ assuming cloud water $\mathrm{pH}=5.0-6.0$ (blue) and no change in $\Delta^{17} \mathrm{O}\left(\mathrm{SO}_{4}{ }^{2-}\right)$ with a $40-50 \%$ increase in $\left[\mathrm{H}_{2} \mathrm{O}_{2}\right]$ between the mid-19th century and the present day assuming cloud water $\mathrm{pH}=5.0(\mathrm{red})$ and 6.0 (yellow). (B) Changes in $\left[\mathrm{RO}_{2}\right]$ and $\left[\mathrm{O}_{3}\right]$ matching the $5.6 \%$ decline in $\Delta^{17} \mathrm{O}\left(\mathrm{NO}_{3}{ }^{-}\right)$from the 1860 s to the present day assuming $\leq 5 \%$ change in $[\mathrm{OH}]$. Grey shading indicate the range of preindustrial to present-day changes in $\left[\mathrm{O}_{3}\right]$ and $[\mathrm{OH}]$ in global CTMs. The dashed line indicate the late 19 th century to present-day change in $\left[\mathrm{O}_{3}\right]$ based on Southern Hemisphere extratropical Schönbein measurements.

$x(\mathrm{OH})$, this implies a local $180-350 \%$ increase in $x\left(\mathrm{RO}_{2}\right)$ in high-latitude Southern Hemisphere $\mathrm{NO}_{\mathrm{x}}$ source regions. CTM studies of preindustrial oxidant chemistry generally do not report changes in $\mathrm{HO}_{2}$ or $\mathrm{RO}_{2}$ species. If future model studies report changes in $\mathrm{RO}_{2}$ in addition to $\mathrm{O}_{3}$, they can use these ice core observations of $\Delta^{17} \mathrm{O}\left(\mathrm{NO}_{3}{ }^{-}\right)$as an additional constraint on paleo-oxidant modeling.

\subsection{Oxidant changes suggested by $\Delta^{17} \mathrm{O}\left(\mathrm{SO}_{4}{ }^{2-}\right)$}

Monte Carlo box model simulations are used to find changes in oxidant abundances that reproduce the observed $1.1 \%$ o increase in $\Delta^{17} \mathrm{O}\left(\mathrm{SO}_{4}{ }^{2-}\right)$ in the early 19 th century. Further constraints are imposed that $x\left(\mathrm{H}_{2} \mathrm{O}_{2}\right)$ does not change, as ice core observations indicate that $\mathrm{H}_{2} \mathrm{O}_{2}$ does not begin to increase until the late 19th century, and $x\left(\mathrm{O}_{3}\right)$ cannot decrease. To match the observed increase in ice core $\Delta^{17} \mathrm{O}\left(\mathrm{SO}_{4}{ }^{2-}\right)$, the fractional increase in the $x\left(\mathrm{O}_{3}\right) / x(\mathrm{OH})$ ratio in the Southern Ocean MBL must be at least $260 \%$, corresponding to an $18 \%$ increase in the fraction of sulfate formed by $\mathrm{O}_{3}$ in the aqueous phase. As shown in Fig. 6a, there is a steep, near-linear relation between the required fractional changes in $x(\mathrm{OH})(-50$ to $-80 \%)$ and $x\left(\mathrm{O}_{3}\right)(0$ to $+120 \%$ ); simulations that match the observed $\Delta^{17} \mathrm{O}\left(\mathrm{SO}_{4}{ }^{2-}\right)$ change due to a large increase in $x\left(\mathrm{O}_{3}\right)$ correspond to a small decrease in $x(\mathrm{OH})$. The minimum $x(\mathrm{OH})$ decrease $(-50 \%)$, which is a much larger decrease than calculated by global models $\left(-33 \%\right.$ to $+14 \%$ ), corresponds to a $17 \mathrm{nmol} \mathrm{mol}^{-1}$ $(125 \%)$ increase in $x\left(\mathrm{O}_{3}\right)$. This fractional change in $x\left(\mathrm{O}_{3}\right)$ is greater than the global average change since the preindustrial period in most global models and is comparable in magnitude to that based on the Schönbein $x\left(\mathrm{O}_{3}\right)$ observations in the Southern Hemisphere extratropics. A global model sensitivity study suggests that a doubling in $x\left(\mathrm{CH}_{4}\right)$, which is much greater than the observed $x\left(\mathrm{CH}_{4}\right)$ increase in the early $1800 \mathrm{~s}$, leads to only a $26 \%$ increase in $x\left(\mathrm{O}_{3}\right) / x(\mathrm{OH})$ and changes in $x(\mathrm{OH})$ and $x\left(\mathrm{O}_{3}\right)$ individually of $\leq 15 \%$ in the Southern Hemisphere extratropics (Fig. A1; see Appendix A). Overall, the early timing and large magnitude of the oxidant changes required to explain the observed $\Delta^{17} \mathrm{O}\left(\mathrm{SO}_{4}{ }^{2-}\right)$ seem highly implausible. This, combined with the fact that ice core observations suggest no significant influence of the non-oxidant factors on sulfate formation, suggests that the change in $\Delta^{17} \mathrm{O}\left(\mathrm{SO}_{4}{ }^{2-}\right)$ may be due to changes in oxidants not considered in the box model analysis. In particular, this analysis points to a decreasing importance of another low$\Delta^{17} \mathrm{O}\left(\mathrm{SO}_{4}{ }^{2-}\right)$-producing oxidant on this timescale. This is discussed further in Sect. 6.5.

The negligible changes in $\Delta^{17} \mathrm{O}\left(\mathrm{SO}_{4}{ }^{2-}\right)$ from 1837 to $2005 \mathrm{CE}$ were previously shown to be consistent with the increases in extratropical Southern Hemisphere $x\left(\mathrm{O}_{3}\right)(25$ to $27 \%)$ and $x\left(\mathrm{H}_{2} \mathrm{O}_{2}\right)(45$ to $51 \%)$, and a decrease in $x(\mathrm{OH})$ $(-15 \%)$ in a CTM between the preindustrial and present day mainly due to the offsetting effects of increasing $x\left(\mathrm{O}_{3}\right)$ and $x\left(\mathrm{H}_{2} \mathrm{O}_{2}\right)$ on $\Delta^{17} \mathrm{O}\left(\mathrm{SO}_{4}{ }^{2-}\right)$ (Kunasek et al., 2010; Sofen et al., 2011). Monte Carlo model results for the time period $1837-2005 \mathrm{CE}$, when $\Delta^{17} \mathrm{O}\left(\mathrm{SO}_{4}{ }^{2-}\right)$ is constant and $x\left(\mathrm{H}_{2} \mathrm{O}_{2}\right)$ increases by $40-50 \%$, are consistent with the oxidant changes mentioned above. However, uncertainties in cloud water $\mathrm{pH}$ and $\Delta{ }^{17} \mathrm{O}\left(\mathrm{O}_{3}\right)$ leads to a wide range in $x\left(\mathrm{O}_{3}\right)$ and $x(\mathrm{OH})$ changes in the Monte Carlo model that match the $\Delta^{17} \mathrm{O}\left(\mathrm{SO}_{4}{ }^{2-}\right)$ observations from 1837 to $2005 \mathrm{CE}$ (Fig. 6b; red and yellow regions). At a pH of 5.0, there is a linear relationship between changes in $x\left(\mathrm{O}_{3}\right)$ and $x(\mathrm{OH})$. At a higher $\mathrm{pH}$, when $\mathrm{O}_{3}$ dominates, $\Delta^{17} \mathrm{O}\left(\mathrm{SO}_{4}{ }^{2-}\right)$ is less sensitive to oxidant changes. Ice core observations suggest a pH of Antarctic precipitation of 5.4 (Cragin et al., 1987); however, it is difficult to directly link ice core acidity to cloud $\mathrm{pH}$. Snow precipitation may overestimate cloud water 
$\mathrm{pH}$ due to dilution of $\left[\mathrm{H}^{+}\right]$in large droplets. On the other hand, "bulk" cloud water chemistry schemes can underestimate cloud water $\mathrm{pH}$ of large droplets, effectively underestimating the importance of $\mathrm{O}_{3}$ in sulfate formation and $\Delta^{17} \mathrm{O}\left(\mathrm{SO}_{4}{ }^{2-}\right)$ (Roelofs, 1993). Better observational constraints on cloud water $\mathrm{pH}$ and $\Delta^{17} \mathrm{O}\left(\mathrm{O}_{3}\right)$ may improve the ability of $\Delta^{17} \mathrm{O}\left(\mathrm{SO}_{4}{ }^{2-}\right)$ to be used to constrain $x\left(\mathrm{O}_{3}\right)$ over this time period. That said, the model (Fig. 6) does suggest that changes in $x\left(\mathrm{O}_{3}\right)$ of $100 \%$ since the late $1800 \mathrm{~s}$, as inferred from remote Southern Hemisphere Schönbein measurements (Sandroni et al., 1992), while not impossible, are difficult to reconcile with the ice core record of $\Delta^{17} \mathrm{O}\left(\mathrm{SO}_{4}{ }^{2-}\right)$, given our present understanding of sulfate formation mechanisms.

\subsection{Sensitivity to ozone isotopic assumption}

As a sensitivity study, we assume $\Delta^{17} \mathrm{O}\left(\mathrm{O}_{3}\right)$ is $35 \%$. The higher isotopic signature of ozone makes it a stronger "lever" on the isotopic composition of nitrate or sulfate, so it slightly reduces the fractional changes in oxidant abundances required to match the observed changes in ice core nitrate and sulfate isotopes. Assuming $\Delta{ }^{17} \mathrm{O}\left(\mathrm{O}_{3}\right)=35 \%$ improves the absolute agreement between the modeled and observed isotopic composition of both sulfate and nitrate. When we assume $\Delta{ }^{17} \mathrm{O}\left(\mathrm{O}_{3}\right)=35 \%$, the $x\left(\mathrm{O}_{3}\right) / x\left(\mathrm{RO}_{2}\right)$ ratio must decrease by $48-84 \%$, with $x\left(\mathrm{O}_{3}\right)$ increasing by up to $110 \%$ and $x\left(\mathrm{RO}_{2}\right)$ increasing by $100-350 \%$ between the $1860 \mathrm{~s}$ and $2000 \mathrm{CE}$ to match the observed decrease in $\Delta^{17} \mathrm{O}\left(\mathrm{NO}_{3}{ }^{-}\right)$. If $x(\mathrm{OH})$ decreases by $33 \%$, then $x\left(\mathrm{O}_{3}\right) / x\left(\mathrm{RO}_{2}\right)$ must decrease by $51-91 \%$. As above, if we consider the range of preindustrial-to-present changes in $x\left(\mathrm{O}_{3}\right)$ from global models and no change in $x(\mathrm{OH})$, a $140-300 \%$ increase in highlatitude Southern Hemisphere $x\left(\mathrm{RO}_{2}\right)$ is implied. In the sulfate model, assuming $\Delta^{17} \mathrm{O}\left(\mathrm{O}_{3}\right)$ is $35 \%$ reduces the magnitude of the change in sulfate formation pathways. To match the observed increase in $\Delta^{17} \mathrm{O}\left(\mathrm{SO}_{4}{ }^{2-}\right)$, an additional $12 \%$ of sulfate formed must be formed via oxidation by ozone, compared to $18 \%$ if $\Delta{ }^{17} \mathrm{O}\left(\mathrm{O}_{3}\right)=25 \%$. This slightly lowers the required change in the $x\left(\mathrm{O}_{3}\right) / x(\mathrm{OH})$ ratio to $210 \%$, rather than $260 \%$. The fractional change in $x(\mathrm{OH})$ also includes slightly smaller changes $(-40$ to $-80 \%)$ than in the base case simulations.

In this sensitivity study, we find that, while unlikely, the nitrate isotope record can be consistent with the $100 \%$ increase in ozone suggested by the late-19th century measurements of surface ozone. In the base case $\left(\Delta^{17} \mathrm{O}\left(\mathrm{O}_{3}\right)=25 \%\right.$ o), the modeled oxidant changes are not consistent with the late19th century ozone measurements. Otherwise, the results of the base case and sensitivity study are quite similar, as the model analysis is focused on fractional changes in oxidant abundances.

\subsection{Impact of reactive halogens on $\Delta^{17} \mathrm{O}$}

Reactive halogens may also impact the formation of both sulfate and nitrate, and hence, their $\Delta^{17} \mathrm{O}$. There is no observation-based information about how the abundance of reactive halogens has changed in the recent past. Here we examine the sensitivity of sulfate and nitrate $\Delta^{17} \mathrm{O}$ and our above conclusions regarding oxidant abundances to reactive halogens.

Including $1 \mathrm{pmol} \mathrm{mol}^{-1} \mathrm{BrO}$ as an oxidant of both $\mathrm{NO}$ and $\mathrm{NO}_{2}$ increases the sensitivity of $\Delta^{17} \mathrm{O}\left(\mathrm{NO}_{3}{ }^{-}\right)$to changes in other oxidants (Fig. 5). If $x(\mathrm{OH})$ does not change between 1863 and $2000 \mathrm{CE}$, then including $\mathrm{BrO}$ in $\mathrm{NO}_{\mathrm{x}}$ cycling slightly reduces the fractional decrease in $x\left(\mathrm{O}_{3}\right) / x\left(\mathrm{RO}_{2}\right)$ ( -58 to $-84 \%$, or -46 to $-79 \%$ if $\Delta^{17} \mathrm{O}\left(\mathrm{O}_{3}\right)=35 \%$ ) required to match the observed change in $\Delta^{17} \mathrm{O}\left(\mathrm{NO}_{3}{ }^{-}\right)$. This is because oxidation by $\mathrm{BrO}$ is a high- $\Delta{ }^{17} \mathrm{O}$ pathway, and with increases in $x\left(\mathrm{O}_{3}\right)$ and $x\left(\mathrm{RO}_{2}\right)$, the relative importance of $\mathrm{BrO}$ declines, reducing $\Delta^{17} \mathrm{O}\left(\mathrm{NO}_{3}{ }^{-}\right)$. However, reactive $\mathrm{Br}$ will also reduce $x\left(\mathrm{O}_{3}\right)$ through its catalytic destruction. While this could potentially further alter $\Delta^{17} \mathrm{O}\left(\mathrm{NO}_{2}\right)$, the changes associated with $\mathrm{NO}_{\mathrm{x}}$ cycling have little impact on $\Delta^{17} \mathrm{O}$, as $\mathrm{NO}+\mathrm{O}_{3}$ and $\mathrm{NO}+\mathrm{BrO}$ have similar isotopic signatures (Savarino et al., 2013). Including $\mathrm{BrO}$ also introduces another daytime nitrate formation pathway $\left(\mathrm{BrONO}_{2}\right.$ hydrolysis), which increases the sensitivity of $\Delta^{17} \mathrm{O}\left(\mathrm{NO}_{3}{ }^{-}\right)$to changes in $x(\mathrm{OH})$, partially offsetting the impact of BrO+NO on the sensitivity of $\Delta^{17} \mathrm{O}\left(\mathrm{NO}_{3}{ }^{-}\right)$to changes in $x\left(\mathrm{O}_{3}\right) / x\left(\mathrm{RO}_{2}\right)$. If we assume the largest decrease in $x(\mathrm{OH})$ from global models $(-33 \%)$ and no other oxidant changes, $\Delta^{17} \mathrm{O}\left(\mathrm{NO}_{3}{ }^{-}\right)$increases by $1.8 \%$ due to the increased importance of $\mathrm{BrONO}_{2}$ hydrolysis in nitrate formation. If $\mathrm{BrO}$ decreases, the primary impact on $\Delta^{17} \mathrm{O}\left(\mathrm{NO}_{3}{ }^{-}\right)$ is a decrease due to the decreased importance of the $\mathrm{BrONO}_{2}$ hydrolysis pathway; the changes associated with $\mathrm{NO}_{\mathrm{x}}$ cycling have little impact on $\Delta^{17} \mathrm{O}\left(\mathrm{NO}_{3}{ }^{-}\right)$, as $\mathrm{NO}+\mathrm{O}_{3}$ and $\mathrm{NO}+\mathrm{BrO}$ have similar isotopic signatures (Savarino et al., 2013).

Introducing a fixed concentration of $\mathrm{HOCl}$ and $\mathrm{HOBr}$ in the sulfate box model reduces the sensitivity of $\Delta^{17} \mathrm{O}\left(\mathrm{SO}_{4}{ }^{2-}\right)$ to changes in other oxidants. Inclusion of this low- $\Delta{ }^{17} \mathrm{O}$ aqueous-phase pathway reduces the fraction of sulfate formed by $\mathrm{O}_{3}$ in both periods, requiring even larger changes in $\mathrm{O}_{3}$ to match the $\Delta^{17} \mathrm{O}\left(\mathrm{SO}_{4}{ }^{2-}\right)$ observations. On the other hand, at very low concentrations of $\mathrm{HOCl}$ and $\mathrm{HOBr}\left(<2 \mathrm{pmol} \mathrm{mol}^{-1}\right), \Delta^{17} \mathrm{O}\left(\mathrm{SO}_{4}{ }^{2-}\right)$ is highly sensitive to changes in $x(\mathrm{HOCl})$ or $x(\mathrm{HOBr})$, with a halving in $x(\mathrm{HOCl})$ or $x(\mathrm{HOBr})$ causing a $1 \%$ increase in $\Delta^{17} \mathrm{O}\left(\mathrm{SO}_{4}{ }^{2-}\right)$. At higher $x(\mathrm{HOCl})$ or $x(\mathrm{HOBr})$, these oxidants dominate aqueous-phase sulfate production, leading to very low $\Delta^{17} \mathrm{O}\left(\mathrm{SO}_{4}{ }^{2-}\right)$ values and little change in $\Delta^{17} \mathrm{O}\left(\mathrm{SO}_{4}{ }^{2-}\right)$ with changing $x(\mathrm{HOCl})$ or $x(\mathrm{HOBr})$ (or other oxidants).

Interestingly, a decrease in the abundance of reactive halogens can qualitatively explain the observed trends in 
$\Delta^{17} \mathrm{O}\left(\mathrm{SO}_{4}{ }^{2-}\right), \Delta^{17} \mathrm{O}\left(\mathrm{NO}_{3}{ }^{-}\right)$, and $[\mathrm{MSA}] /\left[\mathrm{nssSO}_{4}{ }^{2-}\right]$ in the most recent part of the record. However, there is little information about the variability in reactive halogens on this timescale. Murray et al. (2014), using the reactive bromine chemistry scheme of Parrella et al. (2012) in the GEOSChem global chemical transport model, suggests a small increase in $x\left(\mathrm{BrO}_{\mathrm{x}}\right)\left(\mathrm{BrO}_{\mathrm{x}}=\mathrm{Br}+\mathrm{BrO}\right)$, but the production mechanisms in the model are highly parameterized and do not include potentially important anthropogenic impacts such as changes in $\mathrm{pH}$. However, ice core observations suggest little change in acidity in the high southern latitudes over this time period. The $\Delta^{17} \mathrm{O}$ observations will be worth revisiting should new observational and modeling constraints on past reactive halogen abundances be developed.

\section{Conclusions}

We have measured the $\Delta^{17} \mathrm{O}\left(\mathrm{SO}_{4}{ }^{2-}\right), \Delta^{17} \mathrm{O}\left(\mathrm{NO}_{3}{ }^{-}\right)$, and $\delta^{15} \mathrm{~N}\left(\mathrm{NO}_{3}{ }^{-}\right)$from the upper $577 \mathrm{~m}$ of the WAIS Divide ice cores, spanning 2400 years. Based on comparison to other ice core observations, we demonstrate that the long-term increase in $\delta^{15} \mathrm{~N}\left(\mathrm{NO}_{3}{ }^{-}\right)$and decrease in $\Delta^{17} \mathrm{O}\left(\mathrm{NO}_{3}{ }^{-}\right)$can be explained by the impact of the long-term decrease in the snow accumulation rate on the postdepositional loss of snowpack nitrate. However, changes in postdepositional processing cannot explain the $5.6 \%$ decrease in $\Delta^{17} \mathrm{O}\left(\mathrm{NO}_{3}{ }^{-}\right)$ since $1860 \mathrm{CE}$. The $5.6 \%$ downward trend in $\Delta^{17} \mathrm{O}\left(\mathrm{NO}_{3}{ }^{-}\right)$ since 1860 suggests an increase in the importance of $\mathrm{RO}_{2}$ relative to $\mathrm{O}_{3}$ in the oxidation of $\mathrm{NO}$, while there is no apparent change in the formation of nitrate $\left(\mathrm{NO}_{2} \rightarrow \mathrm{HNO}_{3}\right)$. The decrease in $\Delta^{17} \mathrm{O}\left(\mathrm{NO}_{3}{ }^{-}\right)$can be explained by a $60-$ $90 \%$ decrease in the $x\left(\mathrm{O}_{3}\right) / x\left(\mathrm{RO}_{2}\right)$ ratio in extratropical Southern Hemisphere $\mathrm{NO}_{\mathrm{x}}$ source regions, which is qualitatively consistent with our expectations based on global modeling studies. A decrease in the importance of $\mathrm{O}_{3}$ relative to $\mathrm{RO}_{2}$ in $\mathrm{NO}_{\mathrm{x}}$ cycling also leads to an enhancement in the production of $\mathrm{O}_{3}$ by $\mathrm{NO}_{\mathrm{x}}$ cycling. The $1.1 \%$ step increase in $\Delta^{17} \mathrm{O}\left(\mathrm{SO}_{4}{ }^{2-}\right)$ in the early 19 th century suggests a sustained increase in aqueous-phase sulfate production by $\mathrm{O}_{3}$ (with an additional $12-18 \%$ of sulfate being formed by $\mathrm{O}_{3}$ ) compared to gas-phase production by $\mathrm{OH}$, reducing the fraction of sulfate that can contribute to new particle formation over the Southern Ocean. However, the $260 \%$ increase in $x\left(\mathrm{O}_{3}\right) / x(\mathrm{OH})$ required to explain the observed increase in $\Delta^{17} \mathrm{O}\left(\mathrm{SO}_{4}{ }^{2-}\right)$ in the early 19 th century is much too large to be reconciled with a $26 \%$ increase in $x\left(\mathrm{O}_{3}\right) / x(\mathrm{OH})$ from a CTM estimate for the Southern Hemisphere extratropics. This suggests deficiencies in our understanding of remote marine boundary layer sulfate formation, possibly related to sulfate formation involving hypohalous acids $(\mathrm{HOCl}$ and $\mathrm{HOBr}$ ). Observations in the remote MBL of cloud water acidity and hypohalous acids in addition to $\Delta^{17} \mathrm{O}\left(\mathrm{SO}_{4}{ }^{2-}\right)$ may lead to a better understanding of sulfate formation in the

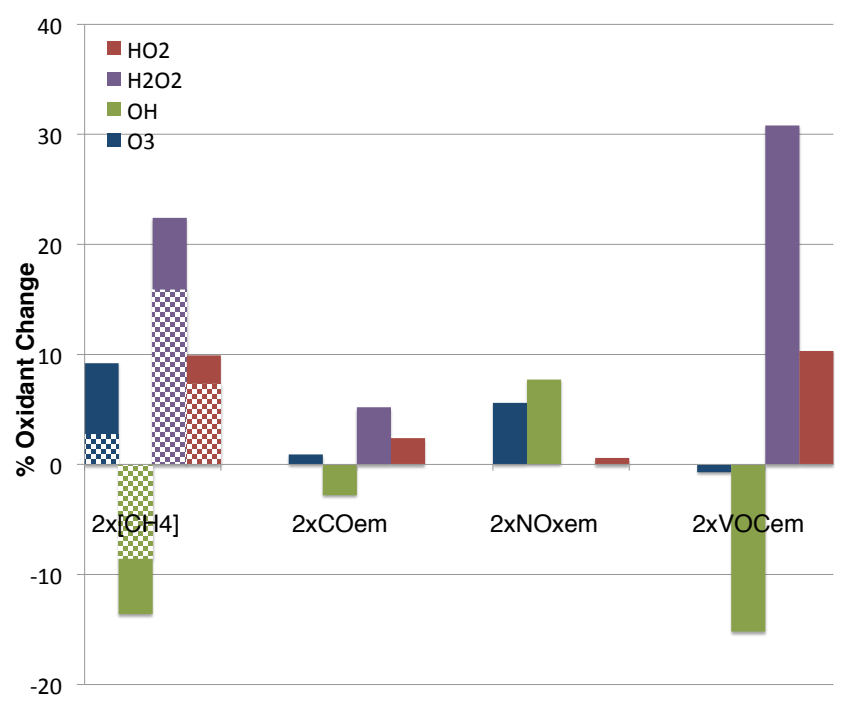

Figure A1. Sensitivity of oxidant concentrations to a doubling in $\left[\mathrm{CH}_{4}\right]$ or emissions of $\mathrm{CO}, \mathrm{NO}_{\mathrm{x}}$, or VOCs relative to a simulation of preindustrial oxidant chemistry (Sofen et al., 2011). Each bar represents the fractional change in Southern Hemisphere extratropical lower tropospheric $(\leq 2 \mathrm{~km})$ oxidant concentration. The checkered segment of the $\mathrm{CH}_{4}$ sensitivity study indicates the fraction of the oxidant changes for which $\mathrm{CH}_{4}$-derived $\mathrm{CO}$ is responsible.

remote MBL and shed light on the record of $\Delta^{17} \mathrm{O}\left(\mathrm{SO}_{4}{ }^{2-}\right)$ from the WAIS Divide ice core.

\section{Appendix A: GEOS-Chem sensitivity studies}

Global model studies report anthropogenic impacts on tropospheric oxidants due to the combined total changes in emissions of $\mathrm{CH}_{4}, \mathrm{CO}$, VOCs, and $\mathrm{NO}_{\mathrm{x}}$ between a preindustrial period (typically 1750-1850) and the present (typically 1985-2010). However, emissions of different oxidant precursors $\left(\mathrm{CH}_{4}, \mathrm{CO}, \mathrm{VOCs}, \mathrm{NO}_{\mathrm{x}}\right)$ have some independence in their variability over this time period. For example, changes in wetlands will impact $\mathrm{CH}_{4}$ without impacting $\mathrm{NO}_{\mathrm{x}} \cdot x\left(\mathrm{CH}_{4}\right)$ began increasing around $1800 \mathrm{CE}$ (Mitchell et al., 2011), prior to changes in other oxidant precursors due to anthropogenic activity. To investigate how possible emissions changes could impact oxidants since the preindustrial period, we conduct emissions sensitivity studies in which emissions of $\mathrm{NO}_{\mathrm{x}}, \mathrm{CO}$, VOCs, or the concentration of $\mathrm{CH}_{4}$ are independently doubled relative to those in a preindustrial simulation in the GEOS-Chem global three-dimensional atmospheric chemistry model (Bey et al., 2001; Sofen et al., 2011). Note that the model does not include recent updates by Mao et al. (2013) that implement $\mathrm{HO}_{2}$ uptake on aerosols. The model uses present-day GEOS-4 meteorology. Anthropogenic emissions are turned off and $x\left(\mathrm{CH}_{4}\right)$ is set to a preindustrial value of $792 \mathrm{nmol} \mathrm{mol}^{-1}$. 
The evolution of preindustrial Southern Hemisphere $\mathrm{NO}_{\mathrm{x}}$, $\mathrm{CO}$, and VOC emissions and concentrations and their impact on oxidants are highly uncertain. The magnitude of the changes in $\mathrm{CH}_{4}$ and $\mathrm{NO}_{\mathrm{x}}$ are similar to the expected changes between the preindustrial and present-day periods, but $\mathrm{CO}$ and VOC emissions sensitivity studies likely overestimate actual changes in their emissions. Figure A1 shows the percent change in Southern Hemisphere extratropical lowertropospheric (five vertical levels; approximately $2 \mathrm{~km}$ ) annual mean oxidant concentration for each sensitivity study. Doubling methane causes increases in $\mathrm{O}_{3}(+9 \%)$ and $\mathrm{HO}_{2}$ $(+10 \%)$, and a decrease in $\mathrm{OH}(-14 \%)$ in the Southern Hemisphere extratropical lower troposphere. It causes an even larger increase in $\mathrm{H}_{2} \mathrm{O}_{2}(+22 \%)$. A portion of the change in oxidants due to doubling methane is due to the change in $\mathrm{CO}$ that is an oxidation byproduct of the $\mathrm{CH}_{4}$ and is shown in the hatched portion of the bar chart. Increasing $x\left(\mathrm{CH}_{4}\right)$ prior to changes in other emissions is qualitatively consistent with the increase in $x\left(\mathrm{O}_{3}\right)$ and decrease in $x(\mathrm{OH})$ suggested by $\Delta^{17} \mathrm{O}\left(\mathrm{SO}_{4}{ }^{2-}\right)$. However, a doubling in $x\left(\mathrm{CH}_{4}\right)$ (Fig. A1), and certainly the relatively small change in $x\left(\mathrm{CH}_{4}\right)$ by the mid-1800s, is not enough to produce the magnitude of $x\left(\mathrm{O}_{3}\right) / x(\mathrm{OH})$ changes inferred from $\Delta^{17} \mathrm{O}\left(\mathrm{SO}_{4}{ }^{2-}\right)$.

Most CTMs assume that preindustrial biomass burning carbon monoxide emissions were $10 \%$ of those in the present day, but recent ice core and firn air observations of carbon monoxide isotopes and concentration suggest that Southern Hemisphere carbon monoxide varied widely over the past millennium, including periods when carbon monoxide was higher than in the present day (Wang et al., 2010). Doubling $\mathrm{CO}$ emissions causes small increases in $\mathrm{O}_{3}(+1 \%)$ and $\mathrm{HO}_{2}$ $(+2 \%)$, a small decrease in $\mathrm{OH}(-3 \%)$ and a larger increase in $\mathrm{H}_{2} \mathrm{O}_{2}(+5 \%)$.

Doubling $\mathrm{NO}_{\mathrm{x}}$ emissions increases Southern Hemisphere extratropical $\mathrm{O}_{3}(+6 \%)$ and $\mathrm{OH}(+8 \%)$ with little influence on $\mathrm{HO}_{2}$ or $\mathrm{H}_{2} \mathrm{O}_{2}(<1 \%)$. Emissions inventories suggest that increases in Southern Hemisphere $\mathrm{NO}_{\mathrm{x}}$ emissions are likely restricted to the low latitudes (van Aardenne et al., 2001). Similarly, we see no change in $\left[\mathrm{NO}_{3}{ }^{-}\right]$in the WAIS Divide ice core. However, $\mathrm{NO}_{\mathrm{x}}$ emissions at low latitudes may have a larger hemispheric influence on $\mathrm{O}_{3}$, as $\mathrm{O}_{3}$ has a longer lifetime than $\mathrm{NO}_{\mathrm{x}}$ itself.

We find that increasing VOC emissions produces large increases in $\mathrm{HO}_{2}(+10 \%)$ and $\mathrm{H}_{2} \mathrm{O}_{2}(+31 \%)$, a decrease in $\mathrm{OH}(-15 \%)$, and little change in $\mathrm{O}_{3}(-1 \%)$ (because the Southern Hemisphere extra tropics are $\mathrm{NO}_{\mathrm{x}}$ limited). One model study of preindustrial VOC emissions suggests that while on the global scale emissions of isoprene decreased and monoterpenes increased between 1854 and 2000 CE, South American emissions of both VOCs increased, but only by $10 \%$ (Tanaka et al., 2012).

The largest changes in oxidant ratios are a $26 \%$ increase in $x\left(\mathrm{O}_{3}\right) / x(\mathrm{OH})$ due to doubling methane and a $9 \%$ decrease in $x\left(\mathrm{O}_{3}\right) / x\left(\mathrm{HO}_{2}\right)$ due to doubling VOCs. Considering the likely impact of these emissions scenarios on 1800s oxidants, estimated emissions changes in the Southern Hemisphere are likely too small to produce the large oxidant changes suggested by $\Delta^{17} \mathrm{O}\left(\mathrm{SO}_{4}{ }^{2-}\right)$, making it difficult to reconcile CTMs with the oxidant changes implied by the ice core $\Delta^{17} \mathrm{O}\left(\mathrm{SO}_{4}{ }^{2-}\right)$. It is difficult to compare the oxidants implied by $\Delta^{17} \mathrm{O}\left(\mathrm{NO}_{3}{ }^{-}\right)$to CTMs directly because $x\left(\mathrm{RO}_{2}\right)$ is not typically diagnosed in global models.

\section{The Supplement related to this article is available online at doi:10.5194/acp-14-5749-2014-supplement.}

Acknowledgements. This work was supported by NSF PLR0538049, NSF AGS-0704169, NSF AGS-1103163, and NSF DPP-0839122. The authors appreciate the support of the WAIS Divide Science Coordination Office at the Desert Research Institute of Reno, Nevada for the collection and distribution of the WAIS Divide ice core and related tasks (Kendrick Taylor, NSF Grants 0230396, 0440817, 0944348; and 0944266 - University of New Hampshire). The National Science Foundation Office of Polar Programs also funds the Ice Drilling Program Office and Ice Drilling Design and Operations group for coring activities; The National Ice Core Laboratory, which curated the core and performed core processing, is funded by the National Science Foundation. Raytheon Polar Services is thanked for logistics support in Antarctica, and the 109th New York Air National Guard for airlift in Antarctica.

Edited by: J. Kaiser

\section{References}

Alexander, B., Savarino J., Barkov, N. I., Delmas, R. J., and Thiemens, M. H.: Climate driven changes in the oxidation pathways of atmospheric sulfur, Geophys. Res. Lett., 29, 1685, doi:10.1029/2002GL014879, 2002.

Alexander, B., Thiemens, M. H., Farquhar, J., Kaufman, A. J., Savarino, J., Delmas, R. J.: East Antarctic ice core sulfur isotope measurements over a complete glacial-interglacial cycle, J. Geopys. Res., 108, 4786, doi:10.1029/2003JD003513, 2003.

Alexander, B., Savarino J., Kreutz, K. J., and Thiemens, M. H.: Impact of preindustrial biomass-burning emissions on the oxidation pathways of tropospheric sulfur and nitrogen, J. Geophys. Res., 109, D08303, doi:10.1029/2003JD004218, 2004.

Alexander, B., Park, R. J., Jacob, D. J., and Gong, S.: Transition metal-catalyzed oxidation of atmospheric sulfur: global implications for the sulfur budget, J. Geophys. Res., 114, D02309, doi:10.1029/2008JD010486, 2009.

Alexander, B., Allman, D. J., Amos, H. M., Fairlie, T. D., Dachs, J., Hegg, D. A., and Sletten, R. S.: Isotopic constraints on the formation pathways of sulfate aerosol in the marine boundary layer of the subtropical northeast Atlantic Ocean, J. Geophys. Res., 117, D06304, doi:10.1029/2011JD016773, 2012.

Arsene, C., Barnes, I., and H. Becker, K.: FT-IR product study of the photo-oxidation of dimethyl sulfide: temperature and $\mathrm{O}_{2}$ partial 
pressure dependence, Phys. Chem. Chem. Phys., 1, 5463-5470, doi:10.1039/A907211J, 1999.

Barkan, E. and Luz, B.: High precision measurements of ${ }^{17} \mathrm{O} /{ }^{16} \mathrm{O}$ and ${ }^{18} \mathrm{O} /{ }^{16} \mathrm{O}$ ratios in $\mathrm{H}_{2} \mathrm{O}$, Rapid Commun. Mass. Sp., 19, 3737-42, doi:10.1002/rcm.2250, 2005.

Bates, T. S., Lamb, B. K., Guenther, A., Dignon, J., and Stoiber, R. E.: Sulfur emissions to the atmosphere from natural sources, J. Atmos. Chem., 14, 315-337, doi:10.1007/BF00115242, 1992.

Beine, H. J. and Krognes, T.: The seasonal cycle of peroxyacetyl nitrate (PAN) in the European Arctic, Atmos. Environ., 34, 933940, doi:10.1016/S1352-2310(99)00288-5, 2000.

Berhanu, T. A., Savarino, J., Bhattacharya, S. K., and Vicars, W. C.: O-17 excess transfer during the $\mathrm{NO}_{2}+\mathrm{O}_{3} \rightarrow \mathrm{NO}_{3}+\mathrm{O}_{2}$ reaction, J. Chem. Phys., 136, 044311, doi:10.1063/1.3666852 2012.

Bey, I., Jacob, D. J., Yantosca, R. M., Logan, J. A., Field, B. D., Fiore, A. M., Li, Q., Liu, H. Y., Mickley, L. J., and Schultz, M. G.: Global modeling of tropospheric chemistry with assimilated meteorology: model description and evaluation, J. Geophys. Res., 106, 23073, doi:10.1029/2001JD000807, 2001.

Blunier, T., Floch, G. L., Jacobi, H.-W., and Quansah, E.: Isotopic view on nitrate loss in Antarctic surface snow, Geophys. Res. Lett., 32, 13501, doi:10.1029/2005GL023011, 2005.

Brenninkmeijer, C. A. M., Janssen, C., Kaiser, J., Röckmann, T., Rhee, T. S., and Assonov, S. S.: Isotope effects in the chemistry of atmospheric trace compounds, Chem. Rev., 103, 5125-5162, doi:10.1021/cr020644k, 2003.

Bretherton, C. S., Widmann, M., Dymnikov, V. P., Wallace, J. M., and Bladé, I.: The effective number of spatial degrees of freedom of a time-varying field, J. Climate, 12, 1990-2009, doi:10.1175/1520-0442(1999)012<1990:TENOSD>2.0.CO;2, 1999.

Cosme, E., Hourdin, F., Genthon, C., and Martinerie, P.: Origin of dimethylsulfide, non-sea-salt sulfate, and methanesulfonic acid in eastern Antarctica, J. Geophys. Res., 110, 3302, doi:10.1029/2004JD004881, 2005.

Cragin, J. H., Giovinetto, M. B., and Gow, A. J.: Baseline acidity of precipitation at the South Pole during the last two millennia, Geophys. Res. Lett., 14, 789-792, doi:10.1029/GL014i008p00789, 1987.

Dubey, M. K., Mohrschladt, R., Donahue, N. M., and Anderson, J. G.: Isotope specific kinetics of hydroxyl radical $(\mathrm{OH})$ with water $\left(\mathrm{H}_{2} \mathrm{O}\right)$ : testing models of reactivity and atmospheric fractionation, J. Phys. Chem. A, 101, 1494-1500, doi:10.1021/jp962332p, 1997.

Eastman, R., Warren, S. G., and Hahn, C. J.: Variations in cloud cover and cloud types over the ocean from surface observations, 1954-2008, J. Climate, 24, 5914-5934, doi:10.1175/2011JCLI3972.1, 2011.

Erbland, J., Vicars, W. C., Savarino, J., Morin, S., Frey, M. M., Frosini, D., Vince, E., and Martins, J. M. F.: Air-snow transfer of nitrate on the East Antarctic Plateau - Part 1: Isotopic evidence for a photolytically driven dynamic equilibrium in summer, Atmos. Chem. Phys., 13, 6403-6419, doi:10.5194/acp-136403-2013, 2013.

Faloona, I.: Sulfur processing in the marine atmospheric boundary layer: a review and critical assessment of mod- eling uncertainties, Atmos. Environ., 43, 2841-2854, doi:10.1016/j.atmosenv.2009.02.043, 2009.

Fegyveresi, J., Alley, R., Spencer, M., Fitzpatrick, J., Steig, E., White, J., McConnell, J., and Taylor, K.: Late-Holocene climate evolution at the WAIS Divide site, West Antarctica: bubble number-density estimates, J. Glaciol., 57, 629-38, doi:10.3189/002214311797409677, 2011.

Feilberg, K. L., Wiegel, A. A., and Boering, K. A.: Probing the unusual isotope effects in ozone formation: Bath gas and pressure dependence of the non-mass-dependent isotope enrichments in ozone, Chem. Phys. Lett., 556, doi:10.1016/j.cplett.2012.10.038, 2013.

Felix, J. D., Elliott, E. M., and Shaw, S. L.: Nitrogen isotopic composition of coal-fired power plant $\mathrm{NO}_{\mathrm{x}}$ : influence of emission controls and implications for global emission inventories, Environ. Sci. Technol., 46, 3528-3535, doi:10.1021/es203355v, 2012.

Fibiger, D. and Hastings, M.: Quantifying the isotopic composition of $\mathrm{NO}_{\mathrm{x}}$ emission sources: an analysis of collection methods, in: EGU General Assembly Conference Abstracts, edited by: Abbasi, A., and Giesen, N., no. EGU2012-10816 in Geophysical Research Abstracts, p. 10816, European Geosciences Union, Vienna, Austria, 2012.

Fogelman, K. D., Walker, D. M., and Margerum, D. W.: Non-metal redox kinetics - hypochlorite and hypochlorous acid reactions with sulfite, Inorg. Chem., 28, 986-993, doi:10.1021/ic00305a002, 1989.

Frey, M. M., Savarino, J., Morin, S., Erbland, J., and Martins, J. M. F.: Photolysis imprint in the nitrate stable isotope signal in snow and atmosphere of East Antarctica and implications for reactive nitrogen cycling, Atmos. Chem. Phys., 9, 86818696, doi:10.5194/acp-9-8681-2009, 2009.

Gromov, S. Jöckel, P., Sander, R., Brenninkmeijer, C. A. M.: A kinetic chemistry tagging technique and its application to modelling the stable isotopic composition of atmospheric trace gases, Atmos. Chem. Phys., 3, 337-364, doi:10.5194/gmd-3-337-2010, 2010.

Guenther, J., Erbacher, B., Krankowsky, D., and Mauersberger, K.: Pressure dependence of two relative ozone formation rate coefficients, Chem. Phys. Lett. 306, 5-6, 209-213, doi:10.1016/S0009-2614(99)00469-8, 1999.

Hastings, M. G., Steig, E. J., and Sigman, D. M.: Seasonal variations in $\mathrm{N}$ and $\mathrm{O}$ isotopes of nitrate in snow at Summit, Greenland: implications for the study of nitrate in snow and ice cores, J. Geophys. Res., 109, D20306, doi:10.1029/2004JD004991, 2004.

Hastings, M. G., Sigman, D. M., and Steig, E. J.: Glacial/interglacial changes in the isotopes of nitrate from the Greenland Ice Sheet Project 2 (GISP2) ice core, Glob. Biogeochem. Cy., 19, GB4024, doi:10.1029/2005GB002502, 2005.

Hastings, M. G., Jarvis, J. C., and Steig, E. J.: Anthropogenic impacts on nitrogen isotopes of ice-core nitrate, Science, 324, 1288, doi:10.1126/science.1170510, 2009.

Hastings, M. G.: Evaluating source, chemistry and climate change based upon the isotopic composition of nitrate in ice cores, IOPC Ser. Earth Environ., 9, 012002, doi:10.1088/17551315/9/1/012002, 2010.

Holland, H. D.: The Chemistry of the Atmosphere and Oceans, chap. 5, John Wiley \& Sons, Inc., New York, p. 154, 1978. 
Holmes, C. D., Prather, M. J., Søvde, O. A., and Myhre, G.: Future methane, hydroxyl, and their uncertainties: key climate and emission parameters for future predictions, Atmos. Chem. Phys., 13, 285-302, doi:10.5194/acp-13-285-2013, 2013.

Honrath, R. E., Peterson, M. C., Guo, S., Dibb, J. E., Shepson, P. B., Campbell, B.: Evidence of $\mathrm{NO}_{\mathrm{x}}$ production within or upon ice particles in the Greenland snowpack, Geophys. Res. Lett., 26, 6, 695-698, doi:10.1029/1999GL900077, 1999.

Jacobi, H.-W., Weller, R., Jones, A., Anderson, P., and Schrems, O.: Peroxyacetyl nitrate (PAN) concentrations in the Antarctic troposphere measured during the photochemical experiment at Neumayer (PEAN'99), Atmos. Environ., 34, 5235-5247, doi:10.1016/S1352-2310(00)00190-4, 2000.

John, J. G., Fiore, A. M., Naik, V., Horowitz, L. W., and Dunne, J. P.: Climate versus emission drivers of methane lifetime against loss by tropospheric OH from 1860-2100, Atmos. Chem. Phys., 12, 12021-12036, doi:10.5194/acp-12-12021-2012, 2012.

Johnston, J. C. and Thiemens, M. H.: The isotopic composition of tropospheric ozone in three environments, J. Geophys. Res., 102, 25395-25404, doi:10.1029/97JD02075, 1997.

Jones, A. E., Wolff, E. W., Ames, D., Bauguitte, S. J.-B., Clemitshaw, K. C., Fleming, Z., Mills, G. P., Saiz-Lopez, A., Salmon, R. A., Sturges, W. T., and Worton, D. R.: The multiseasonal $\mathrm{NO}_{\mathrm{y}}$ budget in coastal Antarctica and its link with surface snow and ice core nitrate: results from the CHABLIS campaign, Atmos. Chem. Phys., 11, 9271-9285, doi:10.5194/acp-119271-2011, 2011.

Kaiser, J., Hastings, M. G., Houlton, B. Z., Röckmann, T., and Sigman, D. M.: Triple oxygen isotope analysis of nitrate using the denitrifier method and thermal decomposition of $\mathrm{N}_{2} \mathrm{O}$, Anal. Chem., 79, 599-607, doi:10.1021/ac061022s, 2007.

Kaufman, Y. and Tanre, D.: Effect of variations in super-saturation on the formation of cloud condensation nuclei, Nature, 369, 4548, doi:10.1038/369045a0, 1994.

Krankowsky, D., Bartecki, F., Klees, G. G., Mauersberger, K., and Schellenbach, K.: Measurement of heavy isotope enrichement in tropospheric ozone, Geophys. Res. Lett., 22, 1713-1716, doi:10.1029/95GL01436, 1995.

Krankowsky, D., Lämmerzahl, Mauersberger, K., Janssen, C., Tuzson, B., and Röckmann, T.: Stratospheric ozone isotope fractionations derived from collected samples, J. Geophys. Res., 112, D08301, doi:10.1029/2006JD007855, 2007.

Kunasek, S. A., Alexander, B., Steig, E. J., Hastings, M. G., Gleason, D. J., and Jarvis, J. C.: Measurements and modeling of $\Delta^{17} \mathrm{O}$ of nitrate in snowpits from Summit, Greenland, J. Geophys. Res., 113, D24302, doi:10.1029/2008JD010103, 2008.

Kunasek, S. A., Alexander, B., Steig, E. J., Sofen, E. D., Jackson, T. L., Thiemens, M. H., McConnell, J. R., Gleason, D. J., and Amos, H. M.: Sulfate sources and oxidation chemistry over the past $\sim 230$ years from sulfur and oxygen isotopes of sulfate in a West Antarctic ice core, J. Geophys. Res., 115, D18313, doi:10.1029/2010JD013846, 2010.

Lamarque, J.-F., Mcconnell, J. R., Shindell, D. T., Orlando, J. J., and Tyndall, G. S.: Understanding the drivers for the 20th century change of hydrogen peroxide in Antarctic ice-cores, Geophys. Res. Lett., 38, L04810, doi:10.1029/2010GL045992, 2011.

Langner, J., Rodhe, H., Crutzen, P. J., and Zimmermann, P.: Anthropogenic influence on the distribution of tropospheric sulphate aerosol, Nature, 359, 712-716, doi:10.1038/359712a0, 1992.
Lee, H.-M., Henze, D. K., Alexander, B., Murray, L. T.: Investigating the sensitivity of surface-level nitrate seasonality in Antarctica to primary sources using a global model, Atmos. Environ., 89, 757-767, doi:10.1016/j.atmosenv.2014.03.003, 2014.

Lelieveld, J. and Dentener, F. J.: What controls tropospheric ozone?, J. Geophys. Res., 105, 3531-3551, doi:10.1029/1999JD901011, 2000.

Liu, Q.: Kinetics of aqueous phase reactions related to ozone depletion in the Arctic troposphere: bromine chloride hydrolysis, bromide ion with ozone, and sulfur((IV)) with bromine and hypobromous acid, Ph.D. thesis, Purdue University, Lafayette, IN, 2002.

Lyons, J. R.: Transfer of mass-independent fractionation in ozone to other oxygen-containing radicals in the atmosphere, Geophys. Res. Lett., 28, 3231-3234, doi:10.1029/2000GL012791, 2001.

Mao, J.,Fan, S., Jacob, D. J., and Travis, K. R.: Radical loss in the atmosphere from $\mathrm{Cu}-\mathrm{Fe}$ redox coupling in aerosols, Atmos. Chem. Phys. 13, 2, 509-519, doi:10.5194/acp-13-5092013, 2013.

Masclin, S., Frey, M. M., Rogge, W. F., and Bales, R. C.: Atmospheric nitric oxide and ozone at the WAIS Divide deep coring site: a discussion of local sources and transport in West Antarctica, Atmos. Chem. Phys., 13, 8857-8877, doi:10.5194/acp-138857-2013, 2013.

McConnell, J. R., Lamorey, G. W., Lambert, S. W., Taylor, K., C.: Continuous Ice-Core Chemical Analyses Using Inductively Coupled Plasma Mass Spectrometry, Environ. Sci. Technol., 36, 711, doi:10.1021/es011088z, 2002.

McConnell, J. R., Edwards, R., Kok, G. L., Flanner, M. G., Zender, C. S., Saltzman, E. S., Banta, J. R., Pasteris, D. R., Carter, M. M., Kahl, J. D. W.: 20th-Century industrial black carbon emissions altered Arctic climate forcing, Science, 317, 1381-1384, doi:10.1126/science.1144856, 2007.

McGwire, K. C., Taylor, K. C., Banta, J. R., and McConnell, J. R.: Identifying annual peaks in dielectric profiles with a selection curve, J. Glaciol., 57, 763-769, doi:10.3189/002214311797409721, 2011.

Michalski, G., Scott, Z., Kabiling, M., and Thiemens, M. H.: First measurements and modeling of $\Delta^{17} \mathrm{O}$ in atmospheric nitrate, J. Geophys. Res., 30, 1870, doi:10.1029/2003GL017015, 2003.

Mitchell, L. E., Brook, E. J., Sowers, T., Mcconnell, J. R., and Taylor, K.: Multidecadal variability of atmospheric methane, 1000-1800 C. E., J. Geophys. Res., 116, G02007, doi:10.1029/2010JG001441, 2011.

Morin, S., Savarino, J., Bekki, S., Gong, S., and Bottenheim, J. W.: Signature of Arctic surface ozone depletion events in the isotope anomaly $\left(\Delta^{17} \mathrm{O}\right)$ of atmospheric nitrate, Atmos. Chem. Phys., 7, 1451-1469, doi:10.5194/acp-7-1451-2007, 2007.

Morin, S., Savarino, J., Frey, M. M., Domine, F., Jacobi, H.-W., Kaleschke, L., and Martins, J. M. F.: Comprehensive isotopic composition of atmospheric nitrate in the Atlantic Ocean boundary layer from $65^{\circ} \mathrm{S}$ to $79^{\circ} \mathrm{N}$, J. Geophys. Res., 114, D05303, doi:10.1029/2008JD010696, 2009.

Morin, S., Sander, R., and Savarino, J.: Simulation of the diurnal variations of the oxygen isotope anomaly $\left(\Delta^{17} \mathrm{O}\right)$ of reactive atmospheric species, Atmos. Chem. Phys., 11, 3653-3671, doi:10.5194/acp-11-3653-2011, 2011. 
Murray, L. T., Mickley, L. J., Kaplan, J. O., Sofen, E. D., Pfeiffer, M., and Alexander, B.: Factors controlling variability in the oxidative capacity of the troposphere since the Last Glacial Maximum, Atmos. Chem. Phys., 14, 3589-3622, doi:10.5194/acp-143589-2014, 2014.

Parish, T. R. and Bromwich, D. H.: Reexamination of the near-surface airflow over the Antarctic continent and implications on atmospheric circulations at high southern latitudes, Mon. Weather Rev., 135, 1961-1973, doi:10.1175/MWR3374.1, 2007.

Park, R. J., Jacob, D. J., Field, B. D., Yantosca, R. M., and Chin, M.: Natural and transboundary pollution influences on sulfate-nitrate-ammonium aerosols in the United States: implications for policy, J. Geophys. Res., 109, D15204, doi:10.1029/2003JD004473, 2004.

Parrella, J. P., Jacob, D. J., Liang, Q., Zhang, Y., Mickley, L. J., Miller, B., Evans, M. J., Yang, X., Pyle, J. A., Theys, N., and Van Roozendael, M.: Tropospheric bromine chemistry: implications for present and pre-industrial ozone and mercury, Atmos. Chem. Phys., 12, 6723-6740, doi:10.5194/acp-12-67232012, 2012.

Pasteris, D. R., McConnell, J. R., and Edwards, R.: High-resolution, continuous method for measurement of acidity in ice cores, Environ. Sci. Technol., 46, 1659-1666, doi:10.1021/es202668n, 2012.

Patris, N., Delmas, R. J., and Jouzel, J.: Isotopic signatures of sulfur in shallow Antarctic ice cores, J. Geophys. Res., 105, 7071-7078, doi:10.1029/1999JD900974, 2000.

Pavelin, E. G., Johnson, C. E., Rughooputh, S., and Toumi, R.: Evaluation of pre-industrial surface ozone measurements made using Schönbein's method, Atmos. Environ., 33, 919-929, doi:10.1016/S1352-2310(98)00257-X, 1999.

Read, K. A., Lewis, A. C., Bauguitte, S., Rankin, A. M., Salmon, R. A., Wolff, E. W., Saiz-Lopez, A., Bloss, W. J., Heard, D. E., Lee, J. D., and Plane, J. M. C.: DMS and MSA measurements in the Antarctic Boundary Layer: impact of BrO on MSA production, Atmos. Chem. Phys., 8, 2985-2997, doi:10.5194/acp-8-2985-2008, 2008.

Roelofs, G.: A cloud chemistry sensitivity study and comparison of explicit and bulk cloud model performance, Atmos. Environ., 27, 2255-2264, doi:10.1016/0960-1686(93)90396-G, 1993.

Saiz-Lopez, A. and von Glasow, R.: Reactive halogen chemistry in the troposphere, Chem. Soc. Rev., 41, 6448-6472, doi:10.1039/C2CS35208G, 2012.

Salawitch, R. J., Gobbi, G. P., Wofsy, S. C., and McElroy, M. B.: Denitrification in the Antarctic stratosphere, Nature, 339, 525527, doi:10.1038/339525a0, 1989.

Sandroni, S., Anfossi, D., and Viarengo, S.: Surface ozone levels at the end of the nineteenth century in South America, J. Geophys. Res., 97, 2535-2539, 1992.

Savarino, J. and Thiemens, M. H.: Analytical procedure to determine both $\delta^{18} \mathrm{O}$ and $\delta^{17} \mathrm{O}$ of $\mathrm{H}_{2} \mathrm{O}_{2}$ in natural water and first measurements, Atmos. Environ., 33, 3683-3690, doi:10.1016/S1352-2310(99)00122-3, 1999.

Savarino, J., Lee, C. C. W., and Thiemens, M. H.: Laboratory oxygen isotopic study of sulfur(IV) oxidation: origin of the massindependent oxygen isotopic anomaly in atmospheric sulfates and sulfate mineral deposits on Earth, J. Geophys. Res., 106, 29079-29088, doi:10.1029/2000JD900456, 2000.
Savarino, J., Alexander, B., Darmohusodo, V., and Thiemens, M. H.: Sulfur and oxygen isotope analysis of sulfate at micromole levels using a pyrolysis technique in a continuous flow system, Anal. Chem., 73, 4457-4462, 2001.

Savarino, J., Kaiser, J., Morin, S., Sigman, D. M., and Thiemens, M. H.: Nitrogen and oxygen isotopic constraints on the origin of atmospheric nitrate in coastal Antarctica, Atmos. Chem. Phys., 7, 1925-1945, doi:10.5194/acp-7-1925-2007, 2007.

Savarino, J., Bhattacharya, S. K., Morin, S., Baroni, M., and Doussin, J.-F.: The $\mathrm{NO}+\mathrm{O}_{3}$ reaction: A triple oxygen isotope perspective on the reaction dynamics and atmospheric implications for the transfer of the ozone isotope anomaly, J. Chem. Phys., 128, 194303, doi:10.1063/1.2917581, 2008.

Savarino, J., Morin, S., Erbland, J., Grannec, F., Patey, M. D., Vicars, W., Alexander, B., and Achterberg, E. P.: Isotopic composition of atmospheric nitrate in a tropical marine boundary layer, P. Natl. Acad. Sci. USA, doi:10.1073/pnas.1216639110, 2013.

Schauer, A. J., Kunasek, S. A., Sofen, E. D., Erbland, J., Savarino, J., Johnson, B. W., Amos, H. M., Shaheen, R., Abaunza, M., Jackson, T. L., Thiemens, M. H., and Alexander, B.: Oxygen isotope exchange with quartz during pyrolysis of silver sulfate and silver nitrate, Rapid Commun. Mass. Sp., 26, 2151-2157, doi:10.1002/rcm.6332, 2012.

Seinfeld, J. H. and Pandis, S. N.: Atmospheric Chemistry and Physics: From Air Pollution to Climate Change, 2nd edn., John Wiley \& Sons, Inc., Hoboken, NJ, 30, 1121-1126, 2006.

Sigman, D. M., Casciotti, K. L., Andreani, M., Barford, C., Galanter, M., and Böhlke, J. K.: A bacterial method for the nitrogen isotopic analysis of nitrate in seawater and freshwater, Anal. Chem., 73, 4145-4153, doi:10.1021/ac010088e, 2001.

Sofen, E. D., Alexander, B., and Kunasek, S. A.: The impact of anthropogenic emissions on atmospheric sulfate production pathways, oxidants, and ice core $\Delta^{17} \mathrm{O}\left(\mathrm{SO}_{4}^{2-}\right)$, Atmos. Chem. Phys., 11, 3565-3578, doi:10.5194/acp-11-3565-2011, 2011.

Spiro, P. A., Jacob, D. J., and Logan, J. A.: Global inventory of sulfur emissions with $1^{\circ} \times 1^{\circ}$ resolution, J. Geophys. Res., 97, 6023-6036, doi:10.1029/91JD03139, 1992.

Tanaka, K., Kim, H.-J., Saito, K., Takahashi, H. G., Watanabe, M., Yokohata, T., Kimoto, M., Takata, K., and Yasunari, T.: How have both cultivation and warming influenced annual global isoprene and monoterpene emissions since the preindustrial era?, Atmos. Chem. Phys., 12, 9703-9718, doi:10.5194/acp-12-97032012, 2012.

Thiemens, M. H.: History and applications of mass-independent isotope effects, Ann. Rev. Earth Pl. Sc., 34, 217-262, doi:10.1146/annurev.earth.34.031405.125026, 2006.

Thiemens, M. H. and Heidenreich, J.: The mass-independent fractionation of oxygen: a novel isotope effect and its possible cosmochemical implications, Science, 219, 1073-1075, doi:10.1126/science.219.4588.1073, 1983.

Troy, R. C. and Margerum, D. W.: Non-metal redox kinetics: Hypobromite and hypobromous acid reactions with iodide and with sulfite and the hydrolysis of bromosulfate, Inorg. Chem., 30, 3538-3543, doi:10.1021/ic00018a028, 1991.

van Aardenne, J. A., Dentener, F. J., Olivier, J. G. J., Klein Goldewijk, C. G. M., and Lelieveld, J.: A $1^{\circ} \times 1^{\circ}$ resolution 
data set of historical anthropogenic trace gas emissions for the period 1890-1990, Glob. Biogeochem. Cy., 15, 909, doi:10.1029/2000GB001265, 2001.

Vicars, W. C., Bhattacharya, S. K., Erbland, J., and Savarino, J.: Measurement of the ${ }^{17} \mathrm{O}$-excess $\left(\Delta^{17} \mathrm{O}\right)$ of tropospheric ozone using a nitrite-coated filter, Rapid Commun. Mass. Sp., 26, 1219-1231, doi:10.1002/rcm.6218, 2012.

Vogt, R., Crutzen, P. J., and Sander, R.: A mechanism for halogen release from sea-salt aerosol in the remote marine boundary layer, Nature, 383, 327-330, doi:10.1038/383327a0, 1996.

von Glasow, R., Sander, R., Bott, A., and Crutzen, P. J.: Modeling halogen chemistry in the marine boundary layer 2 . Interactions with sulfur and the cloud-covered MBL, J. Geophys. Res., 107, 4323, doi:10.1029/2001JD000943, 2002.

von Glasow, R., von Kuhlmann, R., Lawrence, M. G., Platt, U., and Crutzen, P. J.: Impact of reactive bromine chemistry in the troposphere, Atmos. Chem. Phys., 4, 2481-2497, doi:10.5194/acp-42481-2004, 2004.

Wang, Z., Chappellaz, J., Park, K., and Mak, J. E.: Large variations in Southern Hemisphere biomass burning during the last 650 years, Science, 330, 1663-1666, doi:10.1126/science.1197257, 2010.

Weller, R., Traufetter, F., Fischer, H., Oerter, H., Piel, C., and Miller, H.: Postdepositional losses of methane sulfonate, nitrate, and chloride at the European Project for Ice Coring in Antarctica deep-drilling site in Dronning Maud Land, Antarctica, J. Geophys. Res., 109, D07301, doi:10.1029/2003JD004189, 2004.
Wolff, E. W., Jones, A. E., Bauguitte, S. J.-B., and Salmon, R. A.: The interpretation of spikes and trends in concentration of nitrate in polar ice cores, based on evidence from snow and atmospheric measurements, Atmos. Chem. Phys., 8, 5627-5634, doi:10.5194/acp-8-5627-2008, 2008.

Xu, L. and Penner, J. E.: Global simulations of nitrate and ammonium aerosols and their radiative effects, Atmos. Chem. Phys. 12, 9479-9504, doi:10.5194/acp-12-9479-2012, 2012.

Young, P. J., Archibald, A. T., Bowman K. W., Lamarque, J.-F., Naik, V., Stevenson, D. S., Tilmes, S., Voulgarakis, A., Wild, O., Bergmann, D., Cameron-Smith, P., Cionni, I., Collins, W. J., Balsøren, S. B., Doherty, R. M., Eyring, V., Faluvegi, G., Horowitz, L. W., Josse, B., Lee, Y. H., MacKenzie, I. A., Nagashima, T., Plummer, D. A., Righi, M., Rumbold, S. T., Skeie, R. B., Shindell, D. T., Strode, S. A., Sudo, K., Szopa, S., and Zeng, G.: Pre-industrial to end 21st century projections of tropospheric ozone from the Atmospheric Chemistry and Climate Model Intercomparison Project (ACCMIP), Atmos. Chem. Phys., 13, 2063-2090, doi:10.5194/acp-13-2063-2013, 2013.

Zatko, M. C., Grenfell, T. C., Alexander, B., Doherty, S. J., Thomas, J. L., and Yang, X.: The influence of snow grain size and impurities on the vertical profiles of actinic flux and associated $\mathrm{NO}_{\mathrm{x}}$ emissions on the Antarctic and Greenland ice sheets, Atmos. Chem. Phys., 13, 3547-3567, doi:10.5194/acp-13-35472013, 2013. 